IZA DP No. 4940

The Effect of Childhood Conduct Disorder on Human Capital

Pierre Koning

Dinand Webbink

Sunčica Vujić

Nicholas G. Martin

May 2010 


\title{
The Effect of Childhood Conduct Disorder on Human Capital
}

\author{
Pierre Koning \\ CPB Netherlands Bureau for Economic Policy Analysis \\ and IZA \\ Dinand Webbink \\ Erasmus University of Rotterdam (EUR) \\ and CPB Netherlands Bureau for Economic Policy Analysis \\ Sunčica Vujić \\ London School of Economics \\ Nicholas G. Martin \\ Queensland Institute of Medical Research
}
Discussion Paper No. 4940
May 2010

IZA

P.O. Box 7240

53072 Bonn

Germany

Phone: +49-228-3894-0

Fax: +49-228-3894-180

E-mail: iza@iza.org

\begin{abstract}
Any opinions expressed here are those of the author(s) and not those of IZA. Research published in this series may include views on policy, but the institute itself takes no institutional policy positions.

The Institute for the Study of Labor (IZA) in Bonn is a local and virtual international research center and a place of communication between science, politics and business. IZA is an independent nonprofit organization supported by Deutsche Post Foundation. The center is associated with the University of Bonn and offers a stimulating research environment through its international network, workshops and conferences, data service, project support, research visits and doctoral program. IZA engages in (i) original and internationally competitive research in all fields of labor economics, (ii) development of policy concepts, and (iii) dissemination of research results and concepts to the interested public.
\end{abstract}

IZA Discussion Papers often represent preliminary work and are circulated to encourage discussion. Citation of such a paper should account for its provisional character. A revised version may be available directly from the author. 
IZA Discussion Paper No. 4940

May 2010

\section{ABSTRACT}

\section{The Effect of Childhood Conduct Disorder on Human Capital}

This paper estimates the longer-term effects of childhood conduct disorder on human capital accumulation and violent and criminal behaviour later in life using data of Australian twins. We measure conduct disorder with a rich set of indicators based on diagnostic criteria from psychiatry. Using ordinary least squares (OLS) and twin fixed effects (FE) estimation approaches, we find that early (pre-18) conduct disorder problems significantly affect both human capital accumulation and violent and criminal behaviour over the life course. In addition, we find that conduct disorder is more deleterious if these behaviours occur earlier in life.

JEL Classification: I1, I2, K42

Keywords: conduct disorder, human capital, twins

Corresponding author:

Pierre Koning

CPB Netherlands Bureau for Economic Policy Analysis

P.O. BOX 80510

2508 GM The Hague

The Netherlands

E-mail: pwck@cpb.nl 


\section{Introduction}

Many children have mental health problems which hinder their normal development and functioning. Anxiety, conduct, attention, and depressive disorders are the most common. For example, up to 500,000 (14\%) of Australian children between the ages of 4 and 18 years have significant mental health problems (Australian Centre for Community Child Health, 2006); up to 50\% of 'hard to manage' pre-school children are likely to have continuing hardships requiring professional help; approximately one in five children and adolescents in the U.S. may have a mental health disorder (Currie \& Stabile, 2006). Despite these large numbers, little is known on the longer-term effects of these mental health problems of children. Currie \& Stabile (2007) note that most studies 'assume that early mental health problem will have negative effects and focus on the efficacy of specific interventions'. In the economic literature, several recent studies investigate the longer-term effects of mental health problems on human capital. Currie \& Stabile (2006) and Fletcher \& Wolfe (2008) investigate the effects of ADHD in the US and Canada. Fletcher (2008) and Currie \& Stabile (2007) investigate the effect of depression, whereas the latter paper also studies the effects of conduct disorder. Le et al. (2005) analyse the effects of conduct disorder on early school leaving and labour market outcomes in Australia. These papers find that mental disorders, and especially ADHD, have large negative effects on human capital accumulation.

This paper analyses the longer-term effects of childhood conduct disorder on human capital accumulation and violent and criminal behaviour later in life using data of Australian twins. If someone shows "a repetitive and persistent pattern of behaviour in which the basic rights of others or major age-appropriate societal norms or rules are violated,” then he/she falls into a category of individuals with a conduct disorder problem. Conduct disorder is known as a 'disruptive behaviour disorder' because of its impact on children and their families, neighbours, and schools, and is largely associated with delinquent or criminal activity. We measure conduct disorder using diagnostic criteria from the American Psychiatric Association (APA, 1994). In line with Currie \& Stabile (2007) we estimate effects on positive human capital, including measures such as marks in high school and educational attainment, and on 'negative' human capital, including measures such as being arrested, spent time in jail and physically attacking others.

The two main challenges in estimating the longer-term effects of childhood conduct disorder on human capital are the measurement of conduct disorder and omitted variable bias. This paper contributes to the economic literature by addressing these two main challenges. First, it is easy to know when a child has a fever but a child's mental health problem is harder to identify. Typically, mental health problems in children are diagnosed by asking a child's parents and teachers a series of questions about their behaviours. For instance, Currie and Stabile (2007) use 6 questions to form a conduct disorder scale. In this study, we can employ a much richer set of conduct disorder indicators. We use self reports of adult twins on 21 statements that follow the 
definition of conduct disorder according to the APA criteria. In addition, the Diagnostic and Statistical Manual of Mental Disorders (DSM-IV) emphasizes that there should be at least three specific conduct disorder behaviours present within the same 12 month period to make the diagnosis of conduct disorder (APA, 1994). Our data include self reports on a question that exactly matches this definition. Moreover, we have information whether the twin saw a doctor, psychologist or other professional for these behaviours. We used this information for constructing three measures of conduct disorder. Another contribution of this study is that we also have information on the age at which the conduct disorder behaviours occurred. We use this information for investigating the effects of the timing of the problem behaviours on human capital.

Second, estimates of the effect of conduct disorder on human capital might be confounded by unobserved differences between children and their families. For example, in Australia the incidence of mental health problems is even higher in disadvantaged children, such as Aboriginal children (24\%), children residing in 'out of home care’ (55-60\%) and children with a disability, who are up to four times more likely to have mental health problems than children without a disability (Australian Centre for Community Child Health, 2006). Parental substance abuse, marital conflict, psychiatric illness and child abuse and neglect have been identified as risk factors for conduct disorder (Searight, et al. 2001). Previous studies on the effects of childhood mental health problems mainly used cross sectional and within-sibling estimation (Currie and Stabile, 2006, 2007; Fletcher and Wolfe, 2008).

In this paper we estimate within-family models using data of (identical) twins. We are aware of only one previous study (Le et al. 2005) that also uses data on twins. The advantage of using twins instead of siblings is that the family circumstances for twins will typically be more similar than with siblings. More importantly, identical twins are genetically identical, whereas siblings on average only share half of their genetic endowments. Therefore, using data on twins, in particular those that are genetically identical, may reduce the bias caused by heterogeneity within families. In addition, we can further reduce this bias by controlling for differences in birth weight within pairs of identical twins. Recent research has shown that birth weight is an important predictor of later outcomes in life (Black et al., 2007).

We find deleterious effects of conduct disorder on positive and especially on negative human capital, even within pairs of identical twins. For instance, within pairs of identical twins we find that conduct disorder reduces the probability of high school graduation by 4 to 13 percent points and increases the probability of being arrested by 7 to 16 percent points. Another important finding is that the effect of conduct disorder on human capital is more deleterious if these behaviours occur earlier in life. A wide range of robustness checks, for instance sensitivity analyses that address the issue of spill-over effects within pairs of twins, suggest that our main estimates may be lower bounds of the true effect of conduct disorder on human capital. We conclude that childhood mental health problems have high human and financial costs for families and society at large. Effective treatment early in life may yield high returns. 
The remainder of this paper is organised as follows. The next section reviews previous studies. Section 3 describes the data and the methodology is explained in section 4 . Section 5 shows the main estimation results. Robustness checks are presented in Section 6. Section 7 concludes and discusses some policy implications.

\section{Previous studies}

This paper examines the relationship between conduct disorder problems early in life and future human capital accumulation. We focus on conduct disorder problems as a measure of noncognitive traits, as opposed to IQ tests that measure intelligence or cognitive ability. The line between the cognitive and non-cognitive traits is not very clear and has not been consistently defined in either the psychology or economics literature (Borghans et al., 2007).

Two strands of the previous literature are related to our study. The first one, which is probably most similar to our work, consists of health economics papers that look at early childhood health problems and their effects on school performance and educational attainment (Currie and Stabile, 2006a, 2007; Fletcher and Wolfe, 2007, 2008; Fletcher, 2008; Currie and Tekin, 2006; Slade and Wissow, 2007). The second strand of literature examines the relationship between child development, school attainment, and labour market outcomes (Gregg and Machin, 2000; Le et al., 2005).

First, Currie and Stabile (2006) examine the relationship between hyperactivity (ADHD) symptoms and short-term human capital outcomes (test scores, grade repetition, special education, and delinquency) using longitudinal data. The measurement of ADHD was based on questions asked to parents and/or teachers of US children (aged 4-14) or Canadian children (aged 4-11). Using ordinary least squares and within sibling estimation they find large negative effects on test scores and schooling attainment. In a follow up study, Currie and Stabile (2007) also pay attention to depression and conduct disorder (antisocial behaviour/ aggression). Conduct disorder has been measured using 6 questions. They find that children with mental health problems, especially with ADHD, suffer large negative consequences in terms of future human capital outcomes. For the US, they find that conduct disorder has negative effects on various human capital outcomes, while for Canada they find only negative effects on the probability that 16-19 year old youths are in school (fixed effect estimates for the other outcomes suggest negative effects but are statistically insignificant). In this ball park of literature fall recent papers by Fletcher and Wolfe (2007, 2008), Currie and Tekin (2006), Slade and Wissow (2007) and Fletcher (2008). Fletcher and Wolfe (2008) estimate the effect of ADHD on human capital. Measuring ADHD using a series of survey questions, they look at the long-term relationship between childhood symptoms of ADHD and human capital accumulation (grade point average, secondary school indicators, years of education, and probability of attending college). Their OLS results imply that children with ADHD face longer-term 
educational disadvantages. Once family fixed effects are controlled for, standard errors become larger, thus rendering insignificant estimation results. However, they find evidence for spillover effects within families. Fletcher and Wolfe (2007) investigate the effect of ADHD on self reported crime. In specifications that include sibling fixed effects they find that both inattentive and hyperactive symptoms during childhood increase the likelihood of criminal behaviour. Using the U.S. data on adolescent health, Slade and Wissow (2007) look at the connection between childhood maltreatment, which causes emotional and behavioural problems throughout childhood, and academic performance in middle and high school. Using within family estimation they find that more intense childhood maltreatment reduces grade point averages and leads to problems completing homework assignments. Currie and Tekin (2006) investigate the effect of child abuse on crime. Using OLS, propensity score matching estimators and twin fixed effects they find that maltreatment doubles the probability of engaging in many types of crime. The relationship between adolescent depression and educational attainment has been analysed in a recent paper by Fletcher (2008). He finds that depressive symptoms are related to educational attainment. Remarkably, this relationship is only found for females.

Second, Gregg and Machin (2000) examine the relationship between child development and labour market outcomes. Using sequential modelling and UK data, they find that behavioural problems at age 7 are associated with poorer educational outcomes at age 16, which in turn is associated with poor labour market outcomes at ages 23 and 33. Further, the children of parents who grew up in the socially disadvantaged situation during their own childhood have lower early age cognitive abilities, suggesting an important cross-generational link. Le et al. (2005) investigate the effect of childhood conduct disorder on early school leaving and labour market outcomes, such as employment and earnings, in Australia. They find that individuals who experienced conduct disorder problems are more likely to leave school early, have poorer employment prospects and lower earnings. However, the within-twin estimates of the effect of conduct disorder on early school leaving conducted on the sample of identical twins are statistically not significant. They therefore conclude that genetic factors are responsible for the positive link between conduct disorder and early school leaving. In this paper we use the same data as Le et al. (2005) and also investigate the impact of conduct disorder on early school leaving. However, we look at a much broader range of outcomes consisting of six measures of positive human capital and six measures of negative human capital. The new set of indicators of negative human capital, such as aggressive and criminal behaviour, might be more important than the outcomes on positive human capital, because conduct disorder is largely associated with delinquent or criminal activity. In addition, by using three different measures, instead of one measure, of conduct disorder (see next section) we might improve the measurement of conduct disorder. This seems important as mental disorders typically are difficult to observe. 


\section{Data}

In this study, we analyze data from the so-called younger cohort of twins of the Australian Twin Register (ATR). The data were gathered in two surveys, in 1989-1990 and in 1996-2000. In 1980-1982 a sample of 4,262 twin pairs, born between 1964 and 1971, were registered with the ATR as children by their parents in response to media appeals and systematic appeals through the school system. In 1989-1992, when the twins were 18-25 years old, the first survey by mailed questionnaire was conducted, called Alcohol Cohort 2. The response rate of this questionnaire survey was $63 \%$.

In 1996-2000, the second survey was launched, called TWIN89. Telephone interviews were completed with 6,267 individuals, 2,805 men (889 complete and 1,027 incomplete pairs) and 3,462 women (1,215 complete and 1,032 incomplete pairs), who were 30 years old on average (range from 24 to 39) at the time of the interview. The individual response rate for this telephone interview was $86 \%$. The interview was based upon a modified version of the SSAGA (Semi-structured Assessment of the Genetics of Alcoholism), which was developed for the Collaborative Study of the Genetics of Alcoholism (COGA) and is a comprehensive psychiatric interview used to assess physical, psychological, social and psychiatric manifestations of alcohol abuse and dependence and related psychiatric disorders, including conduct disorder. Reliability and validation analysis have been reported in Bucholz et al. (1994) and Hesselbrock et al. (1999). Modifications were made to the SSAGA to incorporate DSM-IV criteria as well as to adapt it for telephone use. Interviews were administered by trained lay interviewers who were blind to the psychiatric status of the co-twin. Interviews were supervised by a qualified clinical psychologist with 4 years of experience who reviewed all interview protocols. In addition, all interviews were tape-recorded and random interview tapes were reviewed for quality control.

The surveys gathered information on the respondent's family background (parents, siblings, marital status, and children), socioeconomic status (education, employment status, and income), health behaviour (body size, smoking and drinking habits), personality, feelings and attitudes. Zygosity was determined by a combination of diagnostic questions plus blood grouping and genotyping.

\section{Conduct disorder}

The measurement of conduct disorder is crucial for our analysis. According to the American Psychiatric Association (APA), a person with conduct disorder problems shows "a repetitive and persistent pattern of behaviour in which the basic rights of others or major age-appropriate societal norms or rules are violated, as manifested by the presence of three (or more) of the following criteria in the past 12 months”. For instance criteria like: often initiated physical fights; has deliberately destroyed others’ property; has broken into someone else's house, building, or a car; has often been truant from school, etc. (for a full definition see Table A.2 in 
the Appendix). Our data contains self-reported information on 21 statements that reflect behavioural problems before the age of 18 (see Table A.1). The information on conduct disorder is based on the second survey among adult twins (ages 24-39). Twins were asked to reflect on their experiences before the age of 18. As our first measure of conduct disorder we created a conduct disorder score based on these 21 statements. We first constructed a conduct disorder index by using factor analysis. However, the main factor appeared to be highly correlated with a conduct disorder score based on summing occurrences of these 21 statements ${ }^{1}$. As this conduct disorder score is more comparable to measures used in previous studies, for instance the 'Antisocial/aggression score' from Currie and Stabile (2007), we prefer to use this measure, which we call the 'Conduct disorder score'. Le et al. (2005) used 19 statements for their measure of conduct disorder ${ }^{2}$. Our second measure of conduct disorder is based on the question 'Did you do at least 3 of these things within the same 12-month period?'. Twins who responded 'yes' were coded as 1 , twins who responded no or twins with a conduct disorder score of 0,1 or 2 were coded as 0 . As this measure perfectly matches the APA definition of conduct disorder we will use it as our main measure in the analysis. We call this measure the ‘APA Definition'. Our survey also asked 'How old were you the first time you did at least 3 of these things within the same 12-month period?'. We use this information for investigating the effect of the timing of conduct disorder. Our third measure of conduct disorder is based on the question 'Did you ever see a doctor, psychologist, social worker or any other professional like that because of these behaviours?'. Twins who responded 'yes' were coded as 1 , twins who responded 'no' or twins who were coded as 0 on the APA definition were coded as 0 on this third measure. We call this measure 'Professional help'. Seeking professional help may signal that conduct disorders hinder normal development and human capital accumulation. Obviously, this measure is endogenous as people choose or are advised to seek professional help. Le et al. (2005) did not use the second and third measures of conduct disorder.

The second measure of conduct disorder, which is directly based on the APA definition, might be a better indicator than the conduct disorder score because of the additional restriction on the time range for the occurrence of the conduct disorders. Small variations on the conduct disorder score (the first definition) might not reflect real differences in conduct disorder if the conduct disorder behaviors occur with relatively large time lags and not within a short period. The psychiatric handbook (DSM-IV) emphasizes that at least three such behaviors should occur within the same 12 month period to make the diagnosis of conduct disorder. The advantage of the third measure is that seeking professional help is a clear signal that the behavior of the child is considered problematic, making it likely that this indicator really measures a difference in conduct disorder. The APA definition of conduct disorder seems the most valid measure because of the precise match with the psychiatric definition. We investigated recall bias by regressing the APA definition of conduct disorder on age (or age and age squared) controlling

\footnotetext{
${ }^{1}$ The correlation between the conduct disorder index based on factor analysis and the conduct disorder score is 0.994 .

${ }^{2}$ We also included 'misbehaved' and 'suspended/expelled'.
} 
for gender, education parents and birth weight. However, all estimates of the age coefficients are statistically insignificant. We also found no evidence for recall bias with respect to the age of onset of conduct disorder.

\section{Positive and negative human capital}

In line with Currie and Stabile (2007), we distinguish between positive and negative human capital. Positive human capital is the type of human capital that is generally accumulated through schooling. Negative human capital is related with criminal, antisocial and violent activities. We use three measures of positive human capital: marks in high school, educational attainment and high school graduation ${ }^{3}$. Marks in high school are measured with a three point scale (below average, average, better than average). Educational attainment was measured using an eight point scale: less than 7 years schooling; 8-10 years schooling; 8-10 years of schooling and apprenticeship or diploma; 11-12 years schooling; apprenticeship, diploma, certificate; technical or teachers' college; university, first degree; university, postgraduate degree. These eight categories have been recorded as 5, 9, 9, 11.5, 11.5, 13, 15 and 17 years of education, respectively (Miller et al., 2006). From this variable we created a dummy for high school graduation (at least 11.5 years of education completed). We also use three measures of 'negative' human capital: 'physically attacking others'; 'being arrested since you were 18'; 'spent time in jail’. All three negative human capital variables are dichotomous variables. Unfortunately, due to the routing of the questionnaire twins with a conduct disorder score of zero did not answer several questions on human capital. As this may bias the estimates downward we checked the sensitivity of the results by imputing mean values on these outcomes for twins with no childhood conduct disorder (see section 6). In the analysis we use as covariates: mother's and father’s education, age, age squared, gender and birth weight.

The main variables in our analysis (conduct disorder, positive and negative human capital) are all based on self reports. The reliability of these self-report data is an important issue. In this paper we use three different measures of conduct disorder and one of our measures is based on 21 statements. We expect that the use of such a rich set of indicators improves the reliability of the data. Self reports on conduct disorder have been shown to have acceptable reliability (Slutsky et al. (1997)). In criminology, a large literature shows that self-report data have consistently acceptable reliability and validity. Many studies find high correlations of selfreport data with other criterion related measures of criminal frequency and arrest histories (Farrington, 1973; Hardt \& Hardt, 1977; Horney \& Marshall, 1992; Huizinga \& Elliott, 1986; Maddux \& Desmond, 1975; Mieczkowski, 1990; Weiss, 1998). Thornberry and Krohn (2000) conclude that "self-reported measures of delinquency are as reliable as, if not more reliable than, most social science measures”.

\footnotetext{
${ }^{3}$ Our data also contains information on grade repetition and marks in primary school. We do not use these measures because it is not clear whether the conduct disorder behaviour, measured before the age of 18, predated or followed these outcomes (reverse causality).
} 
Another issue is the external validity of our sample of Australian twins. Le et al. (2005) compared this twin sample with data of Australian individuals from the Youth in Transition surveys. They found that the twin sample includes a higher proportion of women and that the educational level of twins is slightly higher than in the other surveys. These differences have also been found for other twin samples (Miller et al. 1995; Baker et al. 1996). Le et al. (2005) concluded that the patterns in relation to school leaving decisions are broadly similar to those obtained from samples representative of the general population. Slutsky et al (1997) noted that twins seem representative of the general population with respect to conduct disorder. They also compared the rates of conduct disorder in the so-called older cohort of Australian twins (we use the younger cohort) with the self reported rate of conduct disorder for the general population of the US measured in the National Comorbidity Study ${ }^{4}$. They concluded that the Australian sample did not consistently differ with rates estimated for the general population of the United States. Another issue is that severe cases of conduct disorder might be under sampled or have a higher probability of attrition. We compared the rates of conduct disorder among twins concordant for participation in the second survey with the rates of conduct disorder among twins whose co-twin did not participate in the second survey. If twins with conduct disorder were systematically under sampled, higher rates of conduct disorder would be expected among twins whose co-twin did not participate in the survey (assuming that conduct disorder status is correlated in twin pairs). We found however no difference between the two groups of twins in our sample. Slutsky et al. (1997) and Heath et al. (1998) also found no evidence for cooperation bias or attrition bias in the so-called older cohort of Australian twins. Although these findings suggest that our sample is probably not biased with respect to conduct disorder, it is likely that severe cases of conduct disorder may have been underrepresented.

\section{Descriptive statistics}

Table 3.1 reports means of all measures for pairs of twins with non-missing information on conduct disorder symptoms. Column 1 (3) shows means for complete pairs of all (identical) twins. Column 2 (4) shows the number of twins with a within-family difference in the variable in question for the sample of all (identical) twins.

The top panel shows that the average conduct disorder score is nearly 2. Currie and Stabile (2007) report averages of nearly 5 for the US and 1.5 for Canada using a scale from 0 to 16 . Hence, our Australian sample seems more comparable to the Canadian sample than to the US sample. The second row of table 3.1 shows that 13 percent of our sample would be diagnosed as having conduct disorder according to the APA definition, for men and women this is respectively 20 and $8 \%$. This is roughly in line with Searight et al. (2001) who report that approximately 6 to 16 percent of boys and 2 to 9 percent of girls meet the diagnostic criteria for

${ }^{4}$ We do not include the data of the older cohort in this paper because questions on negative human capital have not been asked. 
conduct disorder. The fraction of our sample that saw professional help is much smaller, approximately 3 percent.

\begin{tabular}{|c|c|c|c|c|}
\hline \multirow[t]{3}{*}{ Means table $f$} & dren wi & all conduct disorc & non-m & sing \\
\hline & \multicolumn{2}{|c|}{ All twin pairs } & \multicolumn{2}{|c|}{ Identical twins } \\
\hline & Mean & Twin differences & Mean & Twin differences \\
\hline \multicolumn{5}{|l|}{ Conduct disorder measures } \\
\hline Conduct disorder score (1-21) & 1.880 & 3596 & 1.674 & 1394 \\
\hline APA definition & 0.131 & 956 & 0.112 & 330 \\
\hline Professional help & 0.027 & 264 & 0.024 & 92 \\
\hline \multicolumn{5}{|l|}{ Positive human capital } \\
\hline Marks high school (1-3) & 2.3 & 2186 & 2.3 & 748 \\
\hline Years of education & 12.2 & 2872 & 12.3 & 1096 \\
\hline High school graduation & 0.792 & 1102 & 0.790 & 197 \\
\hline \multicolumn{5}{|l|}{ Negative human capital } \\
\hline $3+$ Attacking others & 0.192 & 658 & 0.191 & 252 \\
\hline Arrested since 18 & 0.074 & 290 & 0.069 & 102 \\
\hline Jail & 0.019 & 70 & 0.018 & 22 \\
\hline \multicolumn{5}{|l|}{ Covariates } \\
\hline Education mother & 10.3 & & 10.3 & \\
\hline Education father & 10.5 & & 10.5 & \\
\hline Age in 1996 & 29.9 & & 29.9 & \\
\hline Gender (male=1) & 0.442 & & 0.409 & \\
\hline Birth weight (grams) $\mathrm{N}$ & 2540 & & 2430 & \\
\hline $\mathrm{N}$ & 5322 & & 2250 & \\
\hline
\end{tabular}

Note: The column 'Twin differences' shows the number of individuals with a within-twin pair difference on a specific variable.

The number of twins with a within-family difference on one of the three measures of conduct disorder is much larger in the sample of all twins than in the sample of identical twins (column 2 and 4). This illustrates that genetic factors, that are exactly the same within pairs of identical twins, are important for the development of conduct disorder. The average (standard deviation) of the within twin differences for the conduct disorder score is 1.9 (2.5) for the sample of all twins and 1.7 (2.3) for the sample of identical twins. The intra class correlation for the conduct disorder score is 0.63 for identical twins and 0.30 for fraternal twins. The smaller amount of variation in the sample of identical twins makes the estimates more vulnerable for measurement error (Grilliches, 1979) and may limit the opportunities for finding effects on human capital. It should also be noted that the number of pairs used in the estimation may be smaller due to missing values for human capital outcomes.

Table 3.2 shows the distribution of the conduct disorder score for the sample of all twins (column 1) and for both categories of the other two definitions of conduct disorder. 


\begin{tabular}{|c|c|c|c|c|c|}
\hline \multirow{3}{*}{$\begin{array}{l}\text { Table } 3.2 \\
\text { Score }\end{array}$} & \multicolumn{5}{|c|}{ Distribution of conduct disorder score (\% of twins with each score within a column) } \\
\hline & \multirow[t]{2}{*}{ All } & \multicolumn{2}{|c|}{ APA definition } & \multicolumn{2}{|c|}{ Professional help } \\
\hline & & No & Yes & No & Yes \\
\hline 0 & 38.67 & 44.81 & 0.00 & 39.78 & 0.00 \\
\hline 1 & 20.37 & 23.61 & 0.00 & 20.72 & 8.28 \\
\hline 2 & 13.62 & 15.79 & 0.00 & 13.78 & 8.28 \\
\hline 3 & 8.89 & 8.23 & 10.12 & 8.78 & 12.41 \\
\hline 4 & 5.62 & 3.71 & 17.30 & 5.60 & 6.21 \\
\hline 5 & 3.56 & 1.75 & 14.81 & 3.45 & 7.59 \\
\hline 6 & 3.15 & 1.09 & 17.01 & 2.85 & 13.10 \\
\hline 7 & 1.85 & 0.55 & 10.56 & 1.63 & 8.97 \\
\hline 8 & 1.22 & 0.20 & 8.21 & 1.10 & 5.52 \\
\hline 9 & 1.17 & 0.20 & 7.77 & 0.93 & 9.66 \\
\hline 10 & 0.81 & 0.07 & 5.87 & 0.60 & 8.28 \\
\hline 11 & 0.38 & 0.00 & 2.93 & 0.35 & 1.38 \\
\hline 12 & 0.40 & 0.00 & 3.08 & 0.23 & 6.21 \\
\hline 13 & 0.15 & 0.00 & 1.17 & 0.12 & 1.38 \\
\hline 14 & 0.02 & 0.00 & 0.15 & 0.02 & 0.00 \\
\hline 15 & 0.09 & 0.00 & 0.73 & 0.04 & 2.07 \\
\hline 17 & 0.04 & 0.00 & 0.29 & 0.02 & 0.69 \\
\hline Mean & 1.92 & 1.18 & 6.46 & 1.75 & 6.30 \\
\hline $\mathrm{N}$ & 5307 & 4579 & 682 & 5159 & 145 \\
\hline
\end{tabular}

Nearly 39 percent of all twins reported negatively on all 21 statements of conduct disorder and nearly 73 percent have a conduct disorder score of less than three. This distribution is remarkably similar to the distribution of conduct disorder (antisocial/aggression) for Canada reported in Currie and Stabile (2007). As expected, the conduct disorder score for twins that reported 'yes' on the APA definition (column 3) or those who sought professional help (column 5) are much higher, on average more than 5 (4) points higher for the second (third) definition.

The frequencies of specific behaviours underlying the conduct disorder scores are shown in table 3.3. 


\begin{tabular}{|c|c|c|c|c|c|}
\hline \multirow{3}{*}{$\begin{array}{l}\text { Table } 3.3 \\
\text { Item }\end{array}$} & \multirow[t]{3}{*}{ tems } & & & & \\
\hline & & \multicolumn{2}{|c|}{ APA definition } & \multicolumn{2}{|c|}{ Professional help } \\
\hline & & No & Yes & No & Yes \\
\hline Misbehaved in school & 0.148 & 0.095 & 0.489 & 0.136 & 0.593 \\
\hline Wagged school & 0.336 & 0.260 & 0.806 & 0.327 & 0.728 \\
\hline Suspended/expelled & 0.091 & 0.062 & 0.277 & 0.085 & 0.335 \\
\hline Stay out late & 0.183 & 0.118 & 0.594 & 0.176 & 0.474 \\
\hline Sneak out at night & 0.078 & 0.032 & 0.374 & 0.071 & 0.358 \\
\hline Run away overnight & 0.064 & 0.028 & 0.241 & 0.056 & 0.366 \\
\hline Lied, used false name & 0.097 & 0.046 & 0.426 & 0.088 & 0.445 \\
\hline Outsmarted, conned others & 0.065 & 0.028 & 0.301 & 0.060 & 0.262 \\
\hline Stole from home or family & 0.150 & 0.102 & 0.460 & 0.143 & 0.457 \\
\hline Shoplifted & 0.179 & 0.122 & 0.552 & 0.171 & 0.486 \\
\hline Forged signature & 0.003 & 0.001 & 0.016 & 0.003 & 0.029 \\
\hline Damaged property & 0.090 & 0.048 & 0.364 & 0.086 & 0.283 \\
\hline Started physical fights & 0.069 & 0.037 & 0.277 & 0.065 & 0.237 \\
\hline Used a weapon & 0.027 & 0.015 & 0.108 & 0.025 & 0.127 \\
\hline Physically injured someone & 0.065 & 0.043 & 0.207 & 0.063 & 0.173 \\
\hline Bullied others & 0.028 & 0.013 & 0.128 & 0.025 & 0.133 \\
\hline Mean to animals & 0.032 & 0.020 & 0.105 & 0.031 & 0.064 \\
\hline Lighted fires & 0.141 & 0.105 & 0.370 & 0.138 & 0.272 \\
\hline Broke into someone's car/house & 0.068 & 0.027 & 0.331 & 0.062 & 0.289 \\
\hline Forcefully stole money or property & 0.002 & 0.000 & 0.015 & 0.002 & 0.023 \\
\hline Forced someone into sexual activity & 0.001 & 0.000 & 0.010 & 0.001 & 0.006 \\
\hline
\end{tabular}

Behaviours most frequently reported are: wagged school, stay out late, shop lifted, misbehaved at school, stole from home and family. The largest differences between the categories of the second definition (column 2 and 3) and the third definition of conduct disorder (column 4 and 5) are also found on these behaviours.

A first exploration of the relationship between conduct disorder and human capital is shown in figure 3.1. The figure shows Lowess plots of the association between the conduct disorder score and our measures of positive and negative human capital. 
Figure 3.1 The associations between conduct disorder scores and human capital
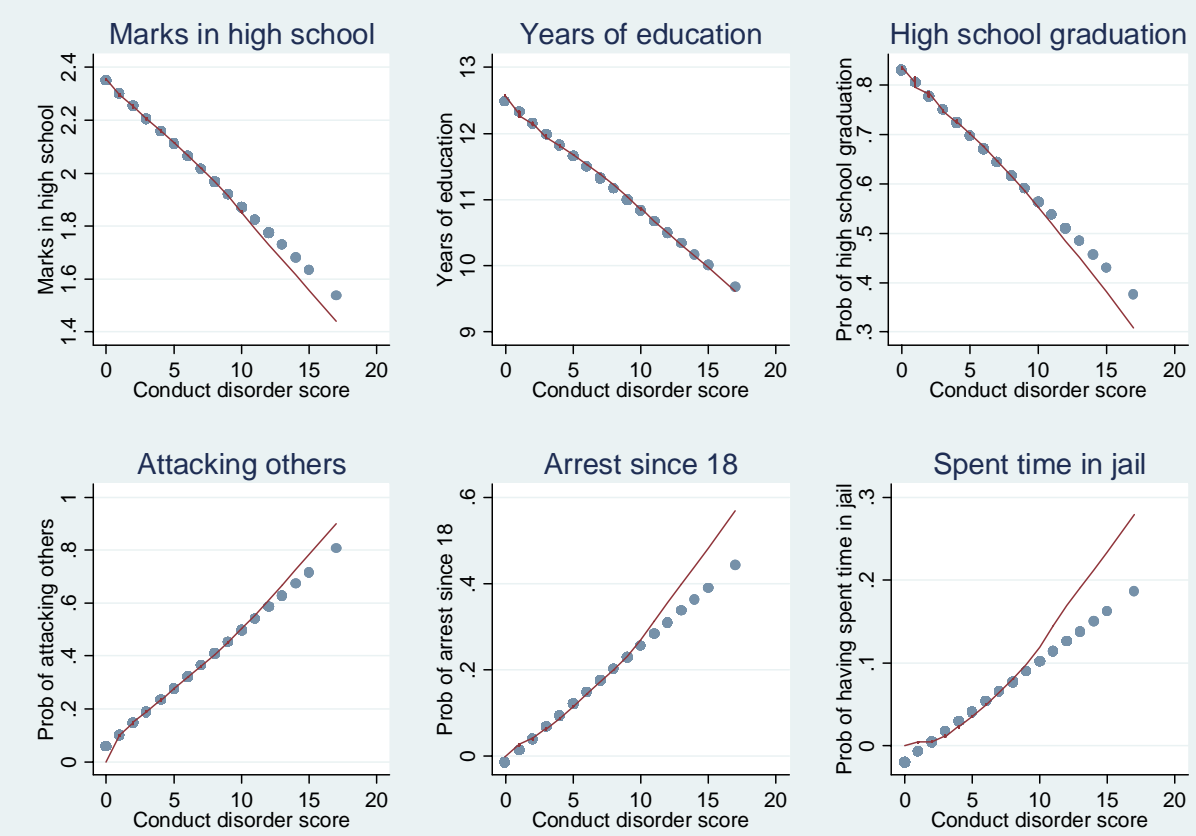

The association between conduct disorder and human capital seems remarkably consistent for all measures of human capital. An increase of conduct disorder is associated with a decrease in positive human capital and increase in negative human capital. For instance, higher levels of conduct disorder are associated with lower marks in high school, less years of education and a lower probability of graduating from high school. In addition, higher levels of conduct disorder are associated with higher probabilities of attacking others, being arrested since the age of 18 or having been incarcerated. In line with previous studies for the US and Canada (Currie and Stabile, 2006, 2007) we find that the association between conduct disorder and human capital seems quite linear. Even low scores of conduct disorder are associated with lower human capital accumulation. 


\section{Methodology}

We follow the same approach as in previous papers on the effects of childhood mental health problems on human capital. First, we estimate OLS models of the relationship between conduct disorder and positive and negative human capital outcomes. As these estimates might be biased by unobserved factors we proceed with estimating within twin fixed effect models:

$$
H C_{i j}=\alpha+\beta C D_{i j}+\gamma X_{i j}+f_{j}+\varepsilon_{i j}
$$

where $H C_{i j}$ is a measure of positive/negative human capital; $C D_{i j}$ is one of our three measures of conduct disorder; $X_{i j}$ is a vector of covariates, consisting of age, gender, birth weight, and mothers' and fathers education; $f_{j}$ captures unobserved family effects common to all twins within the same family, and $\varepsilon_{i j}$ is a random error term. Index $i$ corresponds to the twin number; index $j$ corresponds to the twin family. In this model the family fixed effect is removed by differencing within pairs of twins. We also use OLS and within-twin models for estimating the effect of the age at which conduct disorder behaviours occur on human capital accumulation. Our data contains information on the age of onset of the behaviours according to the APA definition. We created a variable 'years of conduct disorder' as the years before the age of 18 that these behaviours first occurred (18 - age of onset). Hence, twins coded as zero on the APA definition have a value of zero on this variable. Twins with age of onset of 17 have a value of one on this variable; twins with an age of onset of 16 have a value of 2 on this variable. For investigating the effect of age of onset of conduct disorder we estimated the following fixed effect model:

$$
H C_{i j}=\alpha+\text { Byearscd }_{i j}+\delta\left(\text { yearscd }_{i j}\right)^{2}+\gamma X_{i j}+f_{j}+\varepsilon_{i j}
$$

There are several concerns with estimates based on within-family models. First, the estimates might be biased by within-family heterogeneity. Most previous papers on mental health problems of children estimate within-family models using data of siblings. However, siblings may differ in genetic endowments. In addition, the socioeconomic conditions facing siblings and the parental inputs received by siblings may differ if family circumstances change over time. As we use data on (identical) twins it seems less likely that our estimates will be biased by within family heterogeneity. The family circumstances for twins will probably be more equal than for siblings, which differ in age. More importantly, identical twins share exactly the same genes whereas siblings on average only share half of their genetic endowments. By estimating fixed effect models for separate samples of identical twins, we control for all differences in genetic endowments. In addition, we test the robustness of the estimates by excluding pairs of twins with very large differences in educational attainment. These large education differences 
might indicate that these twins are quantitatively different from the rest of the sample and introduce heterogeneity which will confound the effects we are looking for. A potential source of within-family heterogeneity are coexisting conditions such as mood disorders (depression), anxiety, ADHD or substance use disorders. For instance, Currie and Stabile (2007) found that conduct disorder is comorbid with depression and ADHD. These coexisting conditions might induce omitted variable bias. We address this issue by including controls for a large set of selfreported physical and mental health conditions before the age of 14 . These conditions were measured in the first survey. In addition, we control for self-reported depression measured in the second survey. Unfortunately, our data do not include measures of ADHD.

A second concern in within-family models is measurement error. The within-family estimator exacerbates measurement error, which is likely to bias the estimates towards zero (Grilliches, 1979). Unfortunately, our data do not provide a second independent measure of conduct disorder that can be used as an instrumental variable and might solve the problem of measurement error (Ashenfelter, et al. 1994). By using three measures of conduct disorder we aim to mitigate this problem. In addition, we investigated recall bias for (the age of onset of) conduct disorder. We found no evidence for recall bias (see previous section).

A third concern for our analysis is that there might be spill-over effects within pairs of twins. If severe conduct disorder behaviours of one twin also have negative effects on the human capital accumulation of the other twin, then using within twin estimation would underestimate the effect of conduct disorder. Spill-over effects seem quite likely here as conduct disorder is known as a 'disruptive behaviour disorder' because of its impact on children and their families, neighbours, and schools. We address this issue in the same way as Fletcher and Wolfe (2008). They included the mental problems of the other twin in a random effects regression controlling for own mental problems. Although the estimates can be biased by omitted variables they might provide insights on spill-over effects.

\section{Main estimation results}

In this section, we present the main estimation results. Section 5.1 shows the estimates of the effect of conduct disorder on human capital using three measures of conduct disorder. In section 5.2 we investigate whether the age of onset of conduct disorder matters for human capital accumulation.

\subsection{The effect of three measures of conduct disorder on human capital}

We examine the effect of conduct disorder problems, as a measure of non-cognitive traits, on different human capital outcomes using three measures of conduct disorder. Table 5.1 reports the estimated effects of conduct disorder on six types of human capital using linear regression 
(probability) models. The first three columns show the effects of conduct disorder on positive human capital, the last three columns show the estimated effects on negative human capital. The top panel shows the results using the conduct disorder score, the middle panel shows the results for the APA definition of conduct disorder and the bottom panel shows the results using the professional help definition. In each panel we first report OLS estimates, next we report fixed effect estimates for the sample of all twins and finally we report fixed effect estimates for the sample of identical twins. ${ }^{5}$ All regressions include birth weight, age, age squared, gender, and parents' education as controls. Some of these variables drop out from the fixed effect specifications. Each cell shows the results of a separate estimation.

The estimates in table 5.1 suggest that conduct disorder has a negative effect on human capital accumulation and a positive effect on violent and criminal behaviour. The largest effects are found when using the OLS estimation. The size of the estimates reduces when twin fixed effects are taken into account. For the sample of all twins all estimates, except for one, remain statistically significant. The standard errors increase when we restrict the sample to identical twins only. However, even for the sample of identical twins, where the variation in conduct disorder is much smaller than in the sample of all twins (see table 3.1), nearly all estimates of conduct disorder on violent and criminal behaviour are statistically significant.

Most remarkable and compelling are the effects of conduct disorder on negative human capital. The estimates of the effects on the probability of being arrested since the age of 18 and on the probability of spending time in jail seem quite large and robust. In addition, the estimates of the effects of conduct disorder on the probability of physically attacking others are very large for the first two measures of conduct disorder. The estimates of the effects on high school completion are also large although not always statistically significant in the sample of identical twins. The estimates for the third definition suggest that conduct disorder decreases the probability of high school graduation by 13 percent points. The size of these estimates seems large when compared with other covariates. For instance, in the OLS regression we find that one year of father's education is associated an increase of the probability of high school graduation by $2.2 \%$..

\footnotetext{
${ }^{5}$ OLS-estimates for the sample of identical twins are very similar to the OLS-estimates for the total sample of twins. These results can be obtained from the authors on request.
} 


\begin{tabular}{|c|c|c|c|c|c|c|}
\hline \multicolumn{7}{|c|}{ Estimates of the effect of conduct disorder on positive human capital } \\
\hline Conduct Disorder Score & $\begin{array}{r}\text { Marks high } \\
\text { school }\end{array}$ & $\begin{array}{r}\text { Education } \\
\text { years }\end{array}$ & High school & $\begin{array}{r}\text { Attacking } \\
\text { others }\end{array}$ & $\begin{array}{l}\text { Arrested } \\
\text { since } 18\end{array}$ & Jail \\
\hline OLS & $\begin{array}{r}-0.049 \\
(0.004)^{\star \star \star}\end{array}$ & $\begin{array}{r}-0.160 \\
(0.013)^{\star \star \star}\end{array}$ & $\begin{array}{r}-0.026 \\
(0.003)^{\star \star \star}\end{array}$ & $\begin{array}{r}0.041 \\
(0.004)^{\star \star \star}\end{array}$ & $\begin{array}{r}0.026 \\
(0.003)^{\star \star \star}\end{array}$ & $\begin{array}{r}0.014 \\
(0.003)^{\star \star \star}\end{array}$ \\
\hline N & 5270 & 5288 & 5288 & 2180 & 2178 & 2176 \\
\hline Fixed effect All twins & $\begin{array}{r}-0.038 \\
(0.005)^{\star \star \star}\end{array}$ & $\begin{array}{r}-0.082 \\
(0.018)^{\star \star \star}\end{array}$ & $\begin{array}{r}-0.013 \\
(0.003)^{\star \star \star}\end{array}$ & $\begin{array}{r}0.037 \\
(0.006)^{\star \star \star}\end{array}$ & $\begin{array}{r}0.019 \\
(0.004)^{\star \star \star}\end{array}$ & $\begin{array}{r}0.011 \\
(0.002)^{\star \star \star}\end{array}$ \\
\hline $\mathrm{N}$ & 5270 & 5288 & 5288 & 2180 & 2178 & 2176 \\
\hline Fixed effect Identical twins & $\begin{array}{r}-0.017 \\
(0.009)^{\star *}\end{array}$ & $\begin{array}{r}-0.037 \\
(0.032)\end{array}$ & $\begin{array}{r}-0.010 \\
(0.006)\end{array}$ & $\begin{array}{r}0.029 \\
(0.011)^{\star \star \star}\end{array}$ & $\begin{array}{r}0.011 \\
(0.007)\end{array}$ & $\begin{array}{r}0.007 \\
(0.003)^{\star \star}\end{array}$ \\
\hline $\mathrm{N}$ & 2238 & 2236 & 2236 & 888 & 888 & 886 \\
\hline APA Definition & & & & & & \\
\hline OLS & $\begin{array}{r}-0.267 \\
(0.026)^{\star \star \star}\end{array}$ & $\begin{array}{r}-0.818 \\
(0.095)^{\star \star \star}\end{array}$ & $\begin{array}{r}-0.136 \\
(0.019)^{\star \star \star}\end{array}$ & $\begin{array}{r}0.179 \\
(0.022)^{\star \star \star}\end{array}$ & $\begin{array}{r}0.124 \\
(0.017)^{\star \star \star}\end{array}$ & $\begin{array}{r}0.048 \\
(0.011)^{\star \star \star}\end{array}$ \\
\hline N & 5210 & 5226 & 5226 & 2140 & 2138 & 2136 \\
\hline Fixed effect All twins & $\begin{array}{r}-0.180 \\
(0.031)^{\star \star \star}\end{array}$ & $\begin{array}{r}-0.335 \\
(0.111)^{\star \star \star}\end{array}$ & $\begin{array}{r}-0.054 \\
(0.020)^{\star \star \star}\end{array}$ & $\begin{array}{r}0.146 \\
(0.029)^{\star \star \star}\end{array}$ & $\begin{array}{r}0.076 \\
(0.019)^{\star \star \star}\end{array}$ & $\begin{array}{r}0.020 \\
(0.010)^{\star \star}\end{array}$ \\
\hline $\mathrm{N}$ & 5210 & 5226 & 5226 & 2140 & 2138 & 2136 \\
\hline Fixed effect Identical twins & $\begin{array}{r}-0.025 \\
(0.045)\end{array}$ & $\begin{array}{r}-0.095 \\
(0.169)\end{array}$ & $\begin{array}{r}-0.036 \\
(0.032)\end{array}$ & $\begin{array}{r}0.162 \\
(0.044)^{\star \star \star}\end{array}$ & $\begin{array}{r}0.067 \\
(0.028)^{\star \star}\end{array}$ & $\begin{array}{r}0.022 \\
(0.013)^{\star}\end{array}$ \\
\hline $\mathrm{N}$ & 2220 & 2218 & 2218 & 876 & 876 & 874 \\
\hline Professional help & & & & & & \\
\hline OLS & $\begin{array}{r}-0.308 \\
(0.049)^{\star \star \star}\end{array}$ & $\begin{array}{r}-1.135 \\
(0.187)^{\star \star \star}\end{array}$ & $\begin{array}{r}-0.218 \\
(0.040)^{\star \star \star}\end{array}$ & $\begin{array}{r}0.153 \\
(0.045)^{\star \star \star}\end{array}$ & $\begin{array}{r}0.125 \\
(0.038)^{\star \star \star}\end{array}$ & $\begin{array}{r}0.137 \\
(0.035)^{\star \star \star}\end{array}$ \\
\hline $\mathrm{N}$ & 5354 & 5372 & 5372 & 2246 & 2244 & 2242 \\
\hline Fixed effect All twins & $\begin{array}{r}-0.157 \\
(0.059)^{\star \star \star}\end{array}$ & $\begin{array}{r}-0.661 \\
(0.208)^{\star \star \star}\end{array}$ & $\begin{array}{r}-0.126 \\
(0.038)^{\star \star \star}\end{array}$ & $\begin{array}{r}0.022 \\
(0.054)\end{array}$ & $\begin{array}{r}0.061 \\
(0.036)^{\star}\end{array}$ & $\begin{array}{r}0.101 \\
(0.017)^{\star \star \star}\end{array}$ \\
\hline $\mathrm{N}$ & 5354 & 5372 & 5372 & 2246 & 2244 & 2242 \\
\hline Fixed effect Identical twins & $\begin{array}{r}-0.088 \\
(0.085)\end{array}$ & $\begin{array}{r}-0.480 \\
(0.317)\end{array}$ & $\begin{array}{r}-0.130 \\
(0.061)^{\star \star}\end{array}$ & $\begin{array}{r}0.001 \\
(0.085)\end{array}$ & $\begin{array}{r}0.157 \\
(0.054)^{\star \star \star}\end{array}$ & $\begin{array}{r}0.081 \\
(0.025)^{\star \star \star}\end{array}$ \\
\hline $\mathrm{N}$ & 2274 & 2272 & 2272 & 916 & 916 & 914 \\
\hline
\end{tabular}

Note: Each cell contains the estimate of a regression of a human capital measure on conduct disorder. All models control for birth weight, age, age squared, gender and parents' education. Standard errors in brackets. ${ }^{* \star * / * \star / *}$ significant at $1 \% / 5 \% / 10$ $\%$-level.

It should be noted that the sample size is much smaller for the three measures of negative human capital. This is caused by the routing of the questionnaire and may bias the results. In the next section, we will investigate the sensitivity of the results with respect to the smaller sample size. In general, we find the largest effects of conduct disorder for the third measure. It is likely that this measure identifies individuals with severe behaviour problems which hinder their development. The size of the estimates for the first and the second measure seems roughly comparable if we consider that twins with conduct disorder according to the APA definition score approximately 5 points higher on the conduct disorder score. In addition, we constructed a variable similar to the APA definition based on the conduct disorder score only. This variable 
had value 1 if the individual had a conduct disorder score of at least 3 and value zero if the individual had a lower conduct disorder score. Hence, the 12-month restriction has been dropped. We compared the estimation results of the effect of this new variable with the estimation results of the effect of the APA-definition. We find that the size of the estimates is somewhat smaller when using this new variable. In particular, the size of the coefficient estimates increases and becomes similar to the results with the APA-definition when we recode individuals with conduct disorder scores of 3 (4) from one to zero.

\section{Non linearity}

We also investigated whether the effects are non linear by looking at the top percentiles of conduct disorder score. Tables A.3 and A.4 in the appendix show the estimation results of a dummy for having a conduct disorder score of more than 5 or at least 10 . This corresponds to the $90^{\text {th }}$ and $99^{\text {th }}$ percentile. It should be noted that focusing on these top percentiles reduces the variation in conduct disorder that can be used, especially in the sample of identical twins. For most outcomes the estimates suggest that the effects of conduct disorder are quite linear. For instance, for the sample of all twins the within estimates using the dummy for at least 10 conduct disorder behaviours (above the 98 percentile) seem quite comparable with most estimates in table 5.2. Hence, we find no clear evidence for non linear effects of conduct disorder.

\section{Effects of four subscales of conduct disorder}

The APA criteria (see table A.2) suggests that conduct disorder has four underlying components: aggression to people and animals, destruction of property, deceitfulness or theft and serious violations of rules. We investigated the effects of these components by decomposing the conduct disorder score into these four groups of the APA criteria. The estimation results are shown in the appendix (table A.5 and A.6). The results in table A.5 suggest that 'serious violations of rules' are the most important component of conduct disorder for the accumulation of positive human capital. This not very surprising if we consider that this subscale includes items like 'misbehaved' , 'wagged school' and 'suspended/expelled'. For the other subscales the estimates do not show a clear pattern. The estimates of the effect on negative human capital (table A.6) suggest that all subscales are important. The size of the effects of 'aggression' and 'destruction' on 'attacking others' and 'failing to pay debts' is remarkable. 'Destruction', 'deceit/theft' and 'violation of rules' seem the most important factors for the probability of arrest or jail.

\section{Summary}

Using a rich set of indicators of conduct disorder we find large effects of conduct disorder on positive and especially on negative human capital. Even for the smaller sample of identical twins we find substantial effects. These findings corroborate findings from previous studies 
based on within-sibling estimation and using smaller sets of indicators of conduct disorder. Although the within-twin estimates suggest substantial deleterious effects of conduct disorder, these estimates are considerably smaller than the OLS-estimates. This difference between the OLS estimates and the within-twin estimates might result from measurement error in conduct disorder or spill-over effects within pairs of twins. We will address these issues in section 6 .

\section{$5.2 \quad$ The effect of the timing of conduct disorder behaviours}

Several recent studies suggest that the timing of intervention programmes for disadvantaged children is important. For instance, Carneiro and Heckman (2003) show that socio-economic differences in cognitive and non-cognitive abilities appear early in life and widen over the life

cycle of the child. Currie and Stabile (2007) find that early mental health problems have large significant effects on cognitive test scores even controlling for later mental health problems. Loeber (1982) suggests that the earlier a child began displaying antisocial behaviour, the more likely he or she was to persist in such behaviour. Farmer (1995), on the other hand, does not support the hypothesis that earlier onset is associated with more deleterious outcomes. She finds that later onset, rather than earlier, is associated with earlier school leaving and lower level qualifications. In this section we analyse the impact of the timing of conduct disorder behaviours.

Our data contains information on the age of onset of the behaviours according to the APA definition. We created a variable 'onset of conduct disorder' as the years before the age of 18 that these behaviours first occurred (18 - age of onset). The age of onset of conduct disorder appears to be strongly associated with the number of conduct disorder behaviours manifested before the age of 18 (see table A.7). More years of conduct disorder is associated with a higher conduct disorder score. We estimated the effect of the timing of conduct disorder on human capital by including 'years of conduct disorder' and 'years of conduct disorder squared' in our main models (equation (2) from section 4). Table 5.2 shows the estimation results.

The estimates suggest that the timing of conduct disorder behaviours is very important for human capital accumulation. All the estimates corroborate the previous findings and indicate that the effect of conduct disorder on human capital is more deleterious if these behaviours occur earlier. Even in the sample of identical twins we find statistically significant effects of the timing of conduct disorder on grade retention, dropout, high school graduation, attacking other people and the probability of being arrested since the age of 18. The impact of the timing differs between the outcomes. For instance, the quadratic specification suggests that conduct disorder is most deleterious for high school completion when manifested between the ages of 13 to 16 . In addition, the effect of conduct disorder on the probability of arrest since the age of 18 is largest when conduct disorder manifests itself between the ages of 10 to 16 .

We also investigated whether there is a relationship between the socioeconomic background of the twins and the effect of the timing of conduct disorder on human capital. As wealthier 
families have more resources to mitigate conduct disorder problems we might expect smaller effects for twins from these families. We separated our sample in families with a father that completed high school and families with a father that did not complete high school. However, estimations which include an interaction between socioeconomic background and years of conduct disorder show little effect of socioeconomic background. We only find that conduct disorder has a larger effect on the probability of physically attacking others in families in which the father did not complete high school than in other families. Currie and Stabile (2007) also find little evidence that parents income mitigates negative effects of mental health problems of children.

\begin{tabular}{|c|c|c|c|c|c|c|}
\hline Table 5.2 & of the timing & conduct dis & rder on huma & apital & & \\
\hline APA Definition & $\begin{array}{r}\text { Marks high } \\
\text { school }\end{array}$ & $\begin{array}{r}\text { Education } \\
\text { years }\end{array}$ & High school & $\begin{array}{r}\text { Attacking } \\
\text { others }\end{array}$ & $\begin{array}{l}\text { Arrested } \\
\text { since } 18\end{array}$ & Jail \\
\hline \multicolumn{7}{|l|}{ OLS } \\
\hline Years of CD & $\begin{array}{r}-0.110 \\
(0.013)^{\star \star \star}\end{array}$ & $\begin{array}{r}-0.333 \\
(0.043)^{\star \star \star}\end{array}$ & $\begin{array}{r}-0.058 \\
(0.009)^{\star \star \star}\end{array}$ & $\begin{array}{r}0.061 \\
(0.011)^{\star \star \star}\end{array}$ & $\begin{array}{r}0.042 \\
(0.009)^{\star \star \star}\end{array}$ & $\begin{array}{r}0.012 \\
(0.007)^{\star}\end{array}$ \\
\hline Years of $C D$ squared & $\begin{array}{r}0.009 \\
(0.002)^{\star \star \star}\end{array}$ & $\begin{array}{r}0.026 \\
(0.005)^{\star \star \star}\end{array}$ & $\begin{array}{r}0.004 \\
(0.001)^{\star \star \star}\end{array}$ & $\begin{array}{r}-0.004 \\
(0.002)^{\star \star}\end{array}$ & $\begin{array}{r}-0.003 \\
(0.001)^{\star \star}\end{array}$ & $\begin{array}{r}-0.000 \\
(0.001)\end{array}$ \\
\hline $\mathrm{N}$ & 5208 & 5224 & 5224 & 2138 & 2136 & 2134 \\
\hline \multicolumn{7}{|l|}{ Fixed effect All } \\
\hline Years of CD & $\begin{array}{r}-0.083 \\
(0.016)^{\star \star \star}\end{array}$ & $\begin{array}{r}-0.153 \\
(0.056)^{\star \star \star}\end{array}$ & $\begin{array}{r}-0.036 \\
(0.010)^{\star \star \star}\end{array}$ & $\begin{array}{r}0.060 \\
(0.014)^{\star \star \star}\end{array}$ & $\begin{array}{r}0.035 \\
(0.009)^{\star \star \star}\end{array}$ & $\begin{array}{r}0.011 \\
(0.005)^{\star \star}\end{array}$ \\
\hline Years of CD squared & $\begin{array}{r}0.008 \\
(0.002)^{\star \star \star}\end{array}$ & $\begin{array}{r}0.013 \\
(0.007)^{\star}\end{array}$ & $\begin{array}{r}0.004 \\
(0.001)^{\star \star \star}\end{array}$ & $\begin{array}{r}-0.005 \\
(0.002)^{\star \star}\end{array}$ & $\begin{array}{r}-0.003 \\
(0.001)^{\star \star \star}\end{array}$ & $\begin{array}{r}-0.001 \\
(0.001)^{\star \star}\end{array}$ \\
\hline N & 5208 & 5224 & 5224 & 2138 & 2136 & 2134 \\
\hline \multicolumn{7}{|l|}{ Fixed effect Identical } \\
\hline Years of CD & $\begin{array}{r}-0.000 \\
(0.024)\end{array}$ & $\begin{array}{r}-0.009 \\
(0.088)\end{array}$ & $\begin{array}{r}-0.033 \\
(0.017)^{\star}\end{array}$ & $\begin{array}{r}0.056 \\
(0.023)^{\star \star}\end{array}$ & $\begin{array}{r}0.032 \\
(0.014)^{\star \star}\end{array}$ & $\begin{array}{r}0.004 \\
(0.007)\end{array}$ \\
\hline Years of CD squared & $\begin{array}{r}-0.001 \\
(0.003)\end{array}$ & $\begin{array}{r}-0.001 \\
(0.012)\end{array}$ & $\begin{array}{r}0.005 \\
(0.002)^{\star}\end{array}$ & $\begin{array}{r}-0.003 \\
(0.003)\end{array}$ & $\begin{array}{c}-0.003 \\
(0.002)^{*}\end{array}$ & $\begin{array}{r}0.000 \\
(0.001)\end{array}$ \\
\hline $\mathrm{N}$ & 2220 & 2218 & 2218 & 876 & 876 & 874 \\
\hline
\end{tabular}

\section{Summary}

We conclude that the timing of conduct disorder is very important for human capital accumulation. The estimates effects might be lower bounds because measurement error in the age of onset might induce attenuation bias. In line with previous studies, our findings suggests that programmes that succeed in changing conduct disorder behaviours at an early age might yield large returns, both for individuals and society at large. 


\section{Robustness checks}

In this section, we investigate the robustness of the findings. First, we test the sensitivity of the results by imputing missing values on human capital outcomes which are due to the routing of the questionnaire. Second, we exclude pairs of twins with large differences in educational attainment. These large differences might indicate that there are other major differences between these twins. Third, we investigate whether coexisting conditions, such as mood disorders or anxiety, bias the results. Finally, we investigate whether spill-over effects of conduct disorder within pairs of twins play a role. In the robustness checks we mainly use the APA Definition of conduct disorder because of the precise match of this measure with the psychiatric definition.

\section{Missing values due to the routing of the questionnaire}

In the previous section, we noted that the number of observations is much smaller in the estimations of the effect on the measures of negative human capital. Due to the routing of the questionnaire twins with a conduct disorder score of zero did not answer these questions. This may bias the estimates downward as it seems likely that twins with no childhood conduct disorder behaviour will on average accumulate more positive and less negative human capital than twins with problem behaviour early in life. We checked the sensitivity of the results by imputing mean values for twins with missing values on these outcomes and a conduct disorder score of zero. Table 6.1 shows the estimation results for the APA definition of conduct disorder.

\begin{tabular}{|c|c|c|c|}
\hline \multicolumn{4}{|c|}{$\begin{array}{l}\text { Estimates of the effect of conduct disorder (APA definition) on positive and negative human } \\
\text { capital after imputation of missing values due to the routing of the questionnaire }\end{array}$} \\
\hline APA definition & $\begin{array}{r}\text { Attacking } \\
\text { others }\end{array}$ & $\begin{array}{l}\text { Arrested } \\
\text { since } 18\end{array}$ & Jail \\
\hline OLS & $\begin{array}{r}0.176 \\
(0.019)^{\star \star \star *}\end{array}$ & $\begin{array}{r}0.115 \\
(0.015)^{\star \star *}\end{array}$ & $\begin{array}{r}0.043 \\
(0.010)^{\star * *}\end{array}$ \\
\hline $\mathrm{N}$ & 5184 & 5180 & 5178 \\
\hline Fixed effect All twins & $\begin{array}{r}0.158 \\
(0.019)^{\star \star \star}\end{array}$ & $\begin{array}{r}0.084 \\
(0.012)^{\star \star \star}\end{array}$ & $\begin{array}{r}0.025 \\
(0.006)^{\star \star \star}\end{array}$ \\
\hline $\mathrm{N}$ & 5184 & 5180 & 5178 \\
\hline Fixed effect Identical twins & $\begin{array}{r}0.166 \\
(0.030)^{\star \star \star}\end{array}$ & $\begin{array}{r}0.060 \\
(0.018)^{\star \star \star}\end{array}$ & $\begin{array}{r}0.021 \\
(0.008)^{\star \star}\end{array}$ \\
\hline $\mathrm{N}$ & 2200 & 2198 & 2196 \\
\hline
\end{tabular}

After the imputation of these missing values, all estimates become statistically significant. We also observe that the size of most estimates increases. This suggests that due to the routing of the questionnaire we underestimate the deleterious effects of conduct disorder on negative 
human capital. Hence, the size of the estimates in the previous section may be considered as a lower bound of the true effects of conduct disorder on these outcomes.

\section{Excluding pairs of twins with large differences in educational attainment}

As a third robustness check we excluded pairs of twins with large differences in educational attainment. These differences might indicate that these twins are quantitatively different from the rest of the sample and introduce heterogeneity which will confound the effects we are looking for. Table 6.2 shows estimates of the effect of the APA definition of conduct disorder on positive and negative human capital after excluding pairs of twins that differ more than 5.5 years of education.

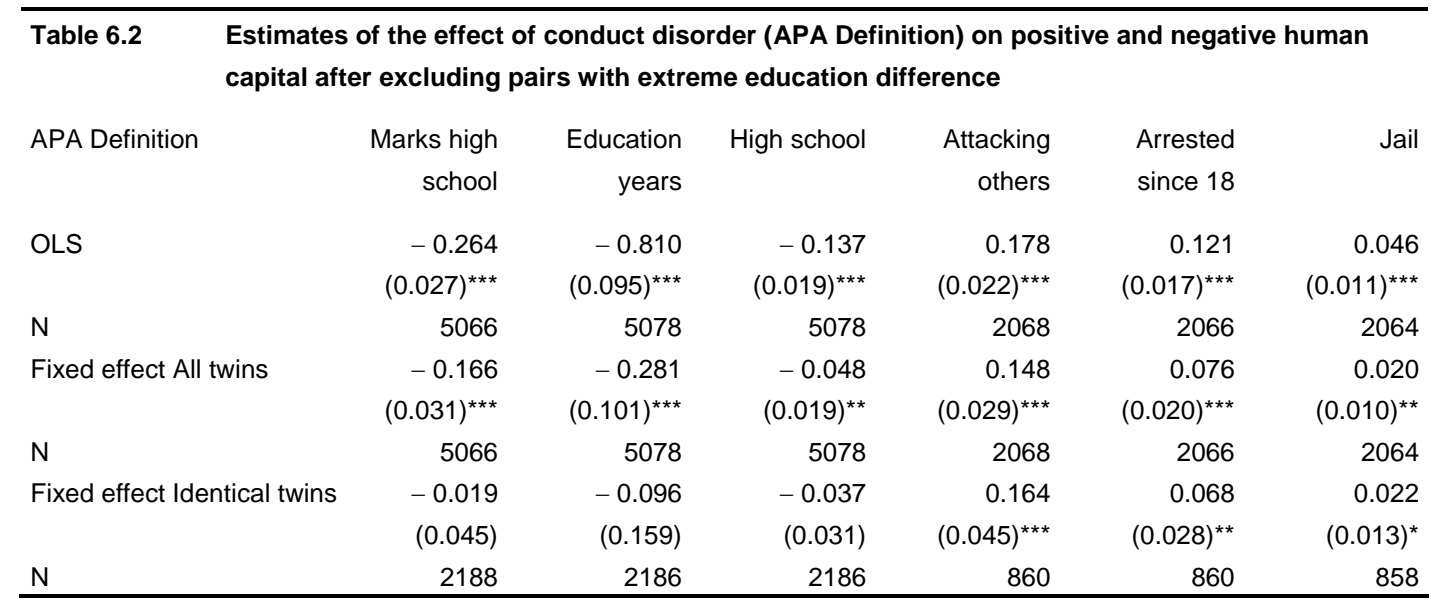

Note: Estimates from regressions of human capital on the APA definition of conduct disorder.

The estimates hardly change after the exclusions of these pairs of twins; the equality between coefficients in table 6.3 and coefficients in previous section cannot be rejected. Hence, the results are robust for exclusion of pairs of twins with large differences in educational attainment.

\section{Comorbidities}

Many children with a conduct disorder may have coexisting conditions such as mood disorders (depression), anxiety, ADHD or substance use disorders. These conditions might bias our estimates. The issue of comorbidity has not been explored extensively in the recent economic literature on the long term effects of mental health. To our knowledge, only Currie and Stabile (2007) have addressed the issue. They find that the incidence of hyperactivity, depression and conduct disorder are correlated across individuals and, therefore, include all mental health scores plus the total combined score in their estimation model. This yields estimation results that are consistent with the results from models that only include one mental health problem, although the estimates are less precise. Their results on the effect of conduct disorder in the 
United States become statistically insignificant after including all other mental health scores. Fletcher (2008), in his study on the effect of depression on educational attainment, also notes that data on comorbid conditions, both physical and mental, are needed.

To address the issue of comorbidity, we included controls for a large set of selfreported physical and mental health conditions before the age of 14 measured in the first survey. Respondents were asked whether they, before they were 14 years old, had had any of the following: Migraine/sick headaches; Depression; Asthma; Alcohol problem; Sudden, involuntary movements (tics); Sudden, involuntary noises or utterances (vocal tics); Involuntary utterance of swear words; Autism; Stuttering or stammering; Diabetes; Epilepsy or suspected epilepsy; Seizure, convulsion; Treatment for schizophrenia; Treatment for manic-depression; Cleft lip; Melanoma; Moles removed. Unfortunately, our data do not include measures of hyperactivity. We included dummies for these 17 conditions in the models that use the APA definition of conduct disorder. The estimation sample becomes smaller due to missing values on these dummies. A comparison of these estimates with estimates of the main model using this smaller sample shows that the estimated effect of conduct disorder on positive and negative human capital hardly changes after the inclusion of these 17 dummies. ${ }^{6}$ In addition, we are able to use measures of depression from the second survey. In particular, respondents were asked: Has there ever been two weeks or more when you were depressed or down most of the day, nearly every day?; Has there ever been two weeks or more when you were a lot less interested in most things or unable to enjoy the things you used to enjoy, most of the day nearly every day? Moreover, the age of onset was asked. From these variables we constructed a dummy variable for depression before the age of 18. Table 6.3 shows the estimation results of the models that include conduct disorder and an indicator of depression before the age of 18 .

\footnotetext{
${ }^{6}$ Results can be obtained from the authors on request.
} 


\begin{tabular}{|c|c|c|c|c|c|c|}
\hline \multirow{2}{*}{$\begin{array}{l}\text { Table } 6.3 \\
\text { APA Definition }\end{array}$} & \multicolumn{6}{|c|}{$\begin{array}{l}\text { Estimates of the effect of conduct disorder (APA Definition) on positive and negative human } \\
\text { capital after including an indicator of depression before the age of } 18\end{array}$} \\
\hline & $\begin{array}{r}\text { Marks high } \\
\text { school }\end{array}$ & $\begin{array}{r}\text { Education } \\
\text { years }\end{array}$ & High school & $\begin{array}{r}\text { Attacking } \\
\text { others }\end{array}$ & $\begin{array}{l}\text { Arrested } \\
\text { since } 18\end{array}$ & Jail \\
\hline \multicolumn{7}{|l|}{ OLS } \\
\hline \multirow[t]{2}{*}{ Conduct disorder } & -0.266 & -0.829 & -0.135 & 0.176 & 0.122 & 0.045 \\
\hline & $(0.026)^{\star \star \star}$ & $(0.095)^{\star \star \star}$ & $(0.019)^{\star \star \star}$ & $(0.022)^{\star \star \star}$ & $(0.017)^{\star \star \star}$ & $(0.010)^{\star \star \star}$ \\
\hline \multirow[t]{2}{*}{ Depression } & -0.016 & 0.138 & -0.017 & 0.050 & 0.046 & 0.044 \\
\hline & $(0.032)$ & $(0.112)$ & $(0.019)$ & $(0.028)^{*}$ & $(0.021)^{\star \star}$ & $(0.015)^{\star \star \star}$ \\
\hline $\mathrm{N}$ & 5210 & 5226 & 5226 & 2140 & 2138 & 2136 \\
\hline \multicolumn{7}{|c|}{ Fixed effect All twins } \\
\hline \multirow[t]{2}{*}{ Conduct disorder } & -0.179 & -0.331 & -0.052 & 0.143 & 0.073 & 0.018 \\
\hline & $(0.031)^{\star \star \star}$ & $(0.112)^{\star \star \star}$ & $(0.020)^{\star \star}$ & $(0.029)^{\star \star \star}$ & $(0.020)^{\star \star \star}$ & $(0.009)^{\star}$ \\
\hline \multirow[t]{2}{*}{ Depression } & -0.021 & -0.051 & -0.040 & 0.052 & 0.049 & 0.047 \\
\hline & $(0.034)$ & $(0.120)$ & $(0.022)^{*}$ & $(0.039)$ & $(0.026)^{\star}$ & $(0.013)^{\star \star \star}$ \\
\hline $\mathrm{N}$ & 5210 & 5226 & 5226 & 2140 & 2138 & 2136 \\
\hline \multicolumn{7}{|c|}{ Fixed Effect Identical twins } \\
\hline \multirow[t]{2}{*}{ Conduct disorder } & -0.019 & -0.069 & -0.030 & 0.155 & 0.068 & 0.021 \\
\hline & $(0.045)$ & $(0.169)$ & $(0.032)$ & $(0.044)^{\star \star \star}$ & $(0.028)^{\star \star}$ & $(0.013)$ \\
\hline \multirow[t]{2}{*}{ Depression } & -0.093 & -0.437 & -0.100 & 0.133 & -0.022 & 0.013 \\
\hline & $(0.048)^{*}$ & $(0.178)^{\star \star}$ & $(0.034)^{\star \star \star}$ & $(0.063)^{\star \star}$ & $(0.040)$ & $(0.019)$ \\
\hline $\mathrm{N}$ & 2220 & 2218 & 2218 & 876 & 876 & 874 \\
\hline
\end{tabular}

Note: Estimates from regressions of human capital on the APA definition of conduct disorder.

Controlling for depression before the age of 18 does not change the results. The estimated effects of conduct disorder in table 6.3 are slightly smaller but very similar to the previous results in table 5.1. Depression during childhood also seems important for both positive and negative human capital which confirms findings by Fletcher (2008). Remarkably, for the indicators of positive human capital the largest effects of depression are found within pairs of identical twins. These findings suggest that the estimates of the effect of conduct disorder on human capital are robust for including measures of coexisting physical or mental health conditions. However, some caution is needed because there might be many coexisting conditions and typically they are difficult to observe. In addition, we do not have measures of hyperactivity which has been found to be comorbid with conduct disorder.

\section{Spill-over effects within pairs of twins}

As a fourth robustness check we investigate whether spill-over effects might be important. Our within-twin estimates will be biased downward if conduct disorder behaviours of one twin also have negative effects on the other twin. We investigated this issue by including the effect of the conduct disorder of the other twin in a random effects regression controlling for own conduct disorder and all controls used in the previous models (education parents, gender, age, age 
squared, birth weight). This approach has also been applied by Fletcher and Wolfe (2008). The estimates are shown in table 6.4.

\begin{tabular}{|c|c|c|c|c|c|c|}
\hline \multicolumn{7}{|c|}{ Random effect estimates of own and sibling's conduct disorder on human capital } \\
\hline APA Definition & $\begin{array}{r}\text { Marks high } \\
\text { school }\end{array}$ & $\begin{array}{r}\text { Education } \\
\text { years }\end{array}$ & High school & $\begin{array}{r}\text { Attacking } \\
\text { others }\end{array}$ & $\begin{array}{l}\text { Arrested } \\
\text { since } 18\end{array}$ & Jail \\
\hline \multirow[t]{2}{*}{ Own conduct disorder } & -0.253 & -0.735 & -0.122 & 0.175 & 0.118 & 0.045 \\
\hline & $(0.023)^{\star \star \star}$ & $(0.092)^{\star \star \star}$ & $(0.016)^{\star \star \star}$ & $(0.020)^{\star \star \star}$ & $(0.013)^{\star \star \star}$ & $(0.007)^{\star \star \star}$ \\
\hline \multirow[t]{2}{*}{ Sibling's disorder } & -0.071 & -0.378 & -0.064 & 0.029 & 0.044 & 0.025 \\
\hline & $(0.023)^{\star \star \star}$ & $(0.091)^{\star \star \star}$ & $(0.016)^{\star \star \star}$ & $(0.019)$ & $(0.013)^{\star \star \star}$ & $(0.007)^{\star \star \star}$ \\
\hline $\mathrm{N}$ & 5210 & 5226 & 5226 & 2140 & 2138 & 2136 \\
\hline
\end{tabular}

Note: Estimates from regressions of human capital on the APA definition of conduct disorder including random effects for twin pairs.

The estimates suggest that the sibling's conduct disorder is important for human capital accumulation. Nearly all the estimates of the effect of the conduct disorder of the other twin are statistically significant and substantially increase the deleterious effects of conduct disorder on human capital. For some measures of human capital, years of education, high school graduation, spent time in jail, we find that the estimated effect of the other twins conduct disorder is approximately half the size of the estimated effect of the own conduct disorder. Although these estimates might be biased by unobserved differences, they indicate that spillover effects within pairs of twins might be important.

In sum, we find that the results in section 5 are robust for various sensitivity checks. If anything, the robustness checks suggest that the estimated effects of conduct disorder on human capital in the previous section might be lower bounds of the true effects.

\section{Conclusions}

In this paper, we examine the relationship between conduct disorder problems before the age of 18 and human capital accumulation. We use three measures of conduct disorder: a 'conduct disorder score' based on 21 statements about behaviour problems, the APA definition (did you do at least three of these behaviours within 12 months) and an indicator of 'professional help' because of conduct disorder. We estimated the effect of conduct disorder on three measures of positive human capital and three measures of negative human capital. The estimates suggest that conduct disorder has a strong effect on violent and criminal behaviour since the age of 18 . In addition, we find that conduct disorder has a negative effect on positive human capital. The effect of conduct disorder on human capital is more deleterious if these behaviours occur earlier in life.

Various robustness checks suggest that these estimates may be lower bounds of the true effect of conduct disorder on human capital. For instance, due to the routing of our survey twins 
with a conduct disorder score of zero did not answer most questions on negative human capital. The size of the estimates increases if we impute the sample means of these outcomes for these twins. In addition, we found evidence for spill-over effects of conduct disorder within pairs of twins. These spill-over effects will bias downward the size of the within twin estimates. It should also be noted that our estimates might be biased towards zero because of measurement error in conduct disorder.

An important and well-known concern with our findings is that unobserved heterogeneity within twin pairs is biasing the results. For instance, one of the twins might be more able than the other twin and this unobserved ability may be correlated with conduct disorder. Unobserved heterogeneity might also come from differences within twins pairs in the treatment of parents. In this paper we addressed this issue by controlling for differences in birth weight within pairs of twins. In addition, we included controls for a large set of self-reported physical and mental health conditions. Moreover, we did a robustness check by excluding pairs of twins with large differences in educational attainment, as these twins might have major differences. These robustness checks did not change our main findings.

Previous research (Currie \& Stabile, 2007) found that conduct disorder before the age of 18 can have large deleterious longer-term effects on positive and negative human capital. Our findings, which are based on a much richer set of indicators of conduct disorder and on data of twins instead of data of siblings, corroborate these results. The magnitude of their estimates on grade repetition is very similar to our findings. In addition, the magnitude of their estimates on young adult delinquency are in the same range as our estimates on attacking others and probability of being arrested ${ }^{7}$. Le et al. (2005), who used the same data, also investigated the effect of the conduct disorder score on one measure of human capital (high school graduation). For the sample of identical twins they find that the estimated effect is not statistically significant. We find basically the same effect for this measure. However, by investigating a much broader set of indicators of human capital and by using three measures of conduct disorder we find strong evidence for detrimental effects of conduct disorder, even in the sample of identical twins. These findings lead us to conclude that conduct disorder decreases investment in positive human capital and increases negative human capital.

Our data also provide the opportunity to investigate whether the timing of conduct disorder matters. In general, we find that earlier occurrence of conduct disorder is more deleterious. This indicates that early intervention is important. Previous studies have shown that early intervention programmes, like the Perry Pre-School Programme (PP-program), the Abecedarian Programme (A-project) or the Head Start Programme (HSP) in the U.S., can be highly effective in 'reducing criminal activity, promoting socioeconomic skills, and integrating disadvantaged

\footnotetext{
${ }^{7}$ Their estimates using a 16 point scale range between 0.01 and 0.034 , where our estimates using a 21 point scale for identical twins range from 0.011 to 0.029
} 
children into mainstream society’ (Carneiro \& Heckman, 2003, Garces et al. 2002, Lally et al. 1988, Schweinhart et al. 1993). These programs may also provide a benchmark for the size of the effects found in this paper. Perhaps the most pronounced effects have been found in the PP-program and the A-project, focused on disadvantaged children. The PP-program increased high school graduation by $20 \%$-points (from 45 to $65 \%$ ) and reduced the proportion being arrested at least 5 times by $19 \%$-points (from 55 to $36 \%$ ). The A-project increased attendance at a four-year college by $22 \%$-points. Our findings, for a population that is on average not disadvantaged, are smaller but still quite substantial. Depending on the measure being used we find that conduct disorder reduces high school graduation with 4 to $13 \%$ and increased the probability of being arrested with 7 to $11 \%$-points.

We conclude that our findings provide further evidence for the consequences of early behaviour problems and the possible gains of effective treatment early in life. 


\section{References}

Ashenfelter, O. and A.B. Krueger, 1994, Estimates of the economic return to schooling from a new sample of twins, American Economic Review, 84(5), 1157-73.

Australian Centre for Community Child Health, 2006, Royal Children’s Hospital Melbourne, Research Centre of the Murdoch Childrens Research Institute, Media Information.

Baker, L.A., Treloar, S.A., Reynolds, C.A., Heath, A.C., Martin, N.G., 1996, Genetics of educational attainment in Australian Twins: Sex differences and secular changes, Behavior Genetics, 26(2), 89-102.

Borghans, L., A.L.Duckworth, J.J. Heckman and B. ter Weel, 2007, The economics and psychology of personality traits, Journal of Human Resources, Vol. 43, no. 4, forthcoming.

Bucholz, K.K., Cadoret, R., Cloninger, C. R., Dinwiddle, S.H., Hesselbrock, V.M., Nurnberger, J.L., Jr. Reich, T., Schmidt, I., Schuckit, M.A., 1994, A new semi-structured psychiatric interview for use in genetic linkage studies: A report on the reliability of the SSAGA, Journal of Studies on Alcohol, 55, 149-158.

Carneiro, P. and J.J. Heckman, 2003, Human Capital Policy, In J.J. Heckman, A.B. Krueger, and B.M. Friedman (Eds.), Inequality in America: What Role for Human Capital Policies? Cambridge, MA: MIT Press.

Currie, J. and M. Stabile, 2006, Child Mental Health and Human Capital Accumulation: The Case of ADHD, Journal of Health Economics, Vol. 25, No. 6, pp. 1094-1118.

Currie, J. and M. Stabile, 2007, Mental Health in Childhood and Human Capital, NBER Working Paper, WP 13217.

Currie, J. and E. Tekin, 2006, Does child abuse cause crime, NBER Working Paper 12171.

Farmer, E.M.Z., 1995, Extremity of Externalizing Behaviour and Young Adult Outcomes, Journal of Child Psychology, Vol. 36, No. 4, pp. 617-632.

Farrington, D. (1973). Self-reports of deviant behavior: Predictive and stable?, Journal of Criminal Law and Criminology, 64(1): 99-110. 
Fletcher, J., 2008, Adolescent depression: diagnosis, treatment, and educational attainment, Health Economics, 17, pp. 1215-1235.

Fletcher, J. and B.L. Wolfe, 2007, Long-term consequences of childhood ADHD on criminal activities, University of Wisconsin-Madison.

Fletcher, J. and B.L. Wolfe, 2008, Child Mental Health and Human Capital Accumulation: The Case of ADHD Revisited, Journal of Health Economics, 27, pp. 794-800.

Garces, E., D. Thomas and J. Currie, 2002, Longer-Term Effects of Head Start, American Economic Review, Vol. 92, No. 4, pp. 999-1012.

Gregg, P. and S. Machin, 2000, Child Development and Success or Failure in the Youth Labour Market, NBER Comparative Labour Market Series (pp. 247-288), Chicago: University of Chicago Press.

Griliches, Z., 1979, Sibling models and data in economics: beginnings of a survey, Journal of Political Economy, 87(5), pp. S37-S64.

Hardt, R. and S. Hardt, 1997, On determining the quality of the delinquency selfreport method, Journal of Research in Crime and Delinquency, July: 247-257.

Heath, A.C., Madden, P.A.F. and N.G. Martin, 1998, Assessing the effects of cooperation bias and attrition in behavioural genetic research using data-weighting, Behavior Genetics, 28(6), 415-427.

Hesselbrock, M., Easton, C., Bucholz, K.K., Schuckit, M., Hesselbrock, V., 1999, A validity study of the SSAGA, a comparison with SCAN, Addiction, 94, 1361-1370.

Horney, J. and I. Marshall, 1992, An experimental comparison of two self-report methods for measuring lambda, Journal of Research in Crime and Delinquency, 29(1): 102-121.

Huizinga, D. and D.S. Elliott, 1986, Reassessing the reliability and validity of self-report delinquency measures, Journal of Quantitative Criminology, 2, 293-327.

Lally, J.R., P. Mangione and A. Honig, 1988, The Syracuse University Family Development Research Programme: Long-Range Impact on an Early Intervention with Low-Income Children and Their Families, In Parent Education as Early Childhood Intervention, Douglas Powell, ed. Norwood, N.J.: Ablex. 
Le, A.T., P.W. Miller, A.C. Heath and N. Martin, 2005, Early childhood behaviours, schooling, and labour market outcomes: estimates from a sample of twins, Economics of Education

Review, Vol. 24, pp. 1-17.

Loeber, R., 1982, The Stability of Antisocial and Delinquent Child Behaviour: A Review, Child Development, Vol. 53, pp. 1431-1446.

Maddux J. and D. Desmond, 1975, Reliability and validity of information from chronic heroin users, Journal of Psychiatric Research, 12(2): 87-95.

Mieczkowski, T., 1990, The accuracy of self-reported drug use: An evaluation and analysis of new data, in R. Weisheit (Ed.), Drugs, crime and the criminal justice system, pp. 275-302.

Cincinnati: Anderson.

Miller, P., C. Mulvey and N. Martin, 1995, What Do Twins Studies Reveal about the Economic Return to Education? A Comparison of Australian and U.S. Findings, American Economics Review, Vol. 85, No. 3, pp. 586-599.

Miller, P., C. Mulvey and N. Martin, 2006, The return to schooling: Estimates from a sample of young Australian twins, Labour Economics, 13, pp. 571-587.

Schweinhart, L., Barnes, H. and Weikart, D. , 1993, Significant Benefits: The High-Scope Perry Pre-School Study through Age 27, Ypsilanti, Mich.: High Scope Press.

Searight, H. R., Rottnek, F., Abby, S.L. , 2001, Conduct disorder: diagnoses and treatment in primary care, American Family Physician, 63 (8), 1579-1588.

Slade, E.P. and L.S. Wissow, 2007, The Influence of Childhood Maltreatment on Adolescents Academic Performance, Economics of Education Review, Vol. 26, No. 5, pp. 604-614.

Slutske, W.S., Heath, A.C., Dinwiddie, S.H., Madden, P.A.F., Bucholz, K.K., Dunne, M.P., Statham, D.J. and N.G. Martin, 1997, Modelling genetic and environmental influences in the etiology of conduct disorder: a study of 2,682 adult twin pairs, Journal of Abnormal Psychology, vol 106 (2), 266-279.

Taylor, N., 2006, Juveniles in Detention in Australia, 1981-2005, Technical and Background Paper 22, Australian Institute of Criminology. 
Thornberry, T.P. and M.D. Krohn, 2000, The self-report method for measuring delinquency and crime, Criminal Justice 2000, Vol. 4, pp. 33-83.

Webbink, H.D., P.W.C. Koning, S. Vujić and N. Martin, 2008, Why are criminals less educated than non-criminals?, CPB Discussion Paper 114.

Weiss, R., L. Najavits, S. Greenfield, J. Soto, S. Shaw and D. Wyner, 1998, Validity of substance use self-reports in dually diagnosed outpatients, American Journal of Psychiatry, 155, 127-128. 


\section{Appendix}

\section{A1. Variable Definitions}

\begin{tabular}{|c|c|}
\hline Table A.1 & t disorder statements from the TWIN89 questionnaire \\
\hline Variable & Question \\
\hline Misbehaved & $\begin{array}{l}\text { L3 Did you frequently get into a lot of trouble with the teacher or principal for misbehaving in } \\
\text { school (primary or secondary school)? }\end{array}$ \\
\hline Wagged school & L4 Before age 18, did you ever wag school for an entire day at least twice in 1 year? \\
\hline Suspended/expelled & L5 Were you ever suspended or expelled from school? \\
\hline Stay out late & L6 As a child or a teenager, did you often stay out much later than you were supposed to? \\
\hline Sneak out at night & L6A Did you often sneak out of the house at night? \\
\hline Run away overnight & L6C Before age 18, did you ever run away from home overnight? \\
\hline Lied, used false name & L7 Before 18, did you ever tell a lot of lies or use a false name or alias? \\
\hline $\begin{array}{l}\text { Outsmarted, conned } \\
\text { others }\end{array}$ & $\begin{array}{l}\text { L7B Before age of 18, was there ever a period when you often outsmarted others and } \\
\text { "conned" them? }\end{array}$ \\
\hline $\begin{array}{l}\text { Stole from home or } \\
\text { family }\end{array}$ & $\begin{array}{l}\text { L8 Before age 18, did you steal money or things from your home or family more than once? If } \\
\text { yes, did you only steal things of trivial value, like loose change or things like that? }\end{array}$ \\
\hline Shoplifted & $\begin{array}{l}\text { L8A Before age 18, did you steal or shoplift from shops or other people (without their } \\
\text { knowing) more than once? If yes, did you only steal things of trivial value like comics or } \\
\text { lollies? }\end{array}$ \\
\hline Forged signature & $\begin{array}{l}\text { L8B Before age 18, did you forge anyone's signature on a cheque or credit card more than } \\
\text { once? }\end{array}$ \\
\hline Damaged property & L9 Have you ever damaged someone's property on purpose? \\
\hline Started physical fights & $\begin{array}{l}\text { L10 Before age 18, did you start physical fights (with persons other than your brothers or } \\
\text { sisters) } 3 \text { or more times? }\end{array}$ \\
\hline Used a weapon & $\begin{array}{l}\text { L11 Before age 18, did you ever use a weapon like a bat, brick, broken bottle, gun or a knife } \\
\text { (other than in combat, when hunting, or as part of your job) to threaten or harm someone? }\end{array}$ \\
\hline $\begin{array}{l}\text { Physically injured } \\
\text { someone }\end{array}$ & $\begin{array}{l}\text { L12 Before age 18, (other than fighting or using a weapon) did you ever physically injure } \\
\text { anyone on purpose? }\end{array}$ \\
\hline Bullied others & L13 Before age 18, were you often a bully, deliberately hurting or being mean to others? \\
\hline Mean to animals & $\begin{array}{l}\text { L14 Before age 18, were you ever mean to animals including pets or did you hurt animals on } \\
\text { purpose? }\end{array}$ \\
\hline Lighted fires & L15 Before 18, did you ever deliberately light any fires you were not supposed to? \\
\hline $\begin{array}{l}\text { Broke into someone's } \\
\text { car/house }\end{array}$ & $\begin{array}{l}\text { L16 Before 18, did you ever break into someone's car or house or anywhere else (not } \\
\text { because you were locked out)? }\end{array}$ \\
\hline $\begin{array}{l}\text { Forcefully stole money } \\
\text { or property }\end{array}$ & $\begin{array}{l}\text { L17 Before age } 18, \text { did you ever take money or property from someone else by threatening } \\
\text { them or using force, like snatching a purse or robbing them? }\end{array}$ \\
\hline $\begin{array}{l}\text { Forced someone into } \\
\text { sexual activity }\end{array}$ & $\begin{array}{l}\text { L20 Before age 18, did you ever force anyone into intercourse or any other form of sexual } \\
\text { activity? }\end{array}$ \\
\hline
\end{tabular}




\section{A.2 APA Criteria for Conduct Disorder}

Table A.2 DSM-IV Diagnostic Criteria for Conduct Disorder $^{\mathrm{a}}$

A Repetitive and persistent pattern of behaviour in which the basic rights of others or major age-appropriate societal norms or rules are violated, as manifested by the presence of three (or more) of the following criteria in the past 12 months, with at least one criterion present in the past 6 months:

\section{Aggression to people and animals}

1. Often bullies, threatens, or intimidate others

2. Often initiates physical fights

3. Has used a weapon that can cause serious physical harm to others (e.g., a bat, brick, broken bottle, knife, gun)

4. Has been physically cruel to people

5. Has been physically cruel to animals

6. Has stolen while confronting a victim (e.g., mugging, purse snatching, extortion, armed robbery)

7. Has forced someone into sexual activity

\section{Destruction of property}

1. Has deliberately engaged in fire setting with the intention of causing serious damage

2. Has deliberately destroyed other's property (other than by fire setting)

\section{Deceitfulness or theft}

1. Has broken into someone else's house, building, or car

2. Often lies to obtain goods or favours to avoid obligations (i.e., "cons" others)

3. Has stolen items of nontrivial value without confronting a victim (e.g., shoplifting, but without breaking and entering; forgery)

\section{Serious violations of rules}

1. Often stays out at night despite parental prohibitions, beginning before age 13 years

2. Has run away from home overnight at least twice while living in parental or parental surrogate home (or once without returning for a lengthy period)

3. Is often truant from school, beginning before age 13 years.

B The disturbance in behaviour causes clinically significant impairment in social, academic, or occupational functioning.

C If the individual is age 18 years or older, criteria are not met for antisocial personality disorder.

Specify severity:

Mild: few if any conduct problems in excess of those required to make the diagnosis and conduct problems cause only minor harms to others.

Moderate: number of conduct problems and effect on others intermediate between "mild" and "severe."

Severe: many conduct problems in excess of those required to make the diagnosis or conduct problems cause considerable harm to others.

${ }^{a}$ Source: American Psychiatric Association. Diagnostic and Statistical Manual of Mental Disorders. 4th ed. Washington, DC: American Psychiatric Association, 1994:98-99. 


\begin{tabular}{|c|c|c|c|c|c|c|}
\hline Table A.3 & Estimates of the effect & nore than 5 & onduct disord & ehaviours & ve 90 perc & \\
\hline$C D>5$ & $\begin{array}{r}\text { Marks high } \\
\text { school }\end{array}$ & $\begin{array}{r}\text { Education } \\
\text { years }\end{array}$ & High school & $\begin{array}{r}\text { Attacking } \\
\text { others }\end{array}$ & $\begin{array}{l}\text { Arrested } \\
\text { since } 18\end{array}$ & Jail \\
\hline OLS & $\begin{array}{r}-0.303 \\
(0.032)^{\star \star *}\end{array}$ & $\begin{array}{r}-0.897 \\
(0.111)^{\star \star \star}\end{array}$ & $\begin{array}{r}-0.158 \\
(0.024)^{\star \star \star}\end{array}$ & $\begin{array}{r}0.198 \\
(0.026)^{\star \star \star}\end{array}$ & $\begin{array}{r}0.137 \\
(0.021)^{\star \star \star}\end{array}$ & $\begin{array}{r}0.075 \\
(0.015)^{\star \star \star}\end{array}$ \\
\hline $\mathrm{N}$ & 5270 & 5288 & 5288 & 2180 & 2178 & 2176 \\
\hline FE All & $\begin{array}{r}-0.207 \\
(0.039)^{\star \star \star}\end{array}$ & $\begin{array}{r}-0.372 \\
(0.136)^{\star \star \star}\end{array}$ & $\begin{array}{r}-0.073 \\
(0.025)^{\star \star \star}\end{array}$ & $\begin{array}{r}0.139 \\
(0.035)^{\star \star *}\end{array}$ & $\begin{array}{r}0.085 \\
(0.023)^{\star \star \star}\end{array}$ & $\begin{array}{r}0.039 \\
(0.011)^{\star \star \star}\end{array}$ \\
\hline $\mathrm{N}$ & 5270 & 5288 & 5288 & 2180 & 2178 & 2176 \\
\hline FE Identical & $\begin{array}{c}-0.103 \\
(0.062)^{\star}\end{array}$ & $\begin{array}{r}-0.207 \\
(0.232)\end{array}$ & $\begin{array}{r}-0.069 \\
(0.044)\end{array}$ & $\begin{array}{r}0.041 \\
(0.062)\end{array}$ & $\begin{array}{r}0.014 \\
(0.039)\end{array}$ & $\begin{array}{r}0.028 \\
(0.018)\end{array}$ \\
\hline $\mathrm{N}$ & 2238 & 2236 & 2236 & 888 & 888 & 886 \\
\hline
\end{tabular}

\begin{tabular}{|c|c|c|c|c|c|c|}
\hline \multirow{2}{*}{$\begin{array}{l}\text { Table A.4 } \\
\text { CD >=10 }\end{array}$} & \multicolumn{6}{|c|}{ Estimates of the effect of at least 10 conduct disorder behaviours (above 98 percentile) } \\
\hline & $\begin{array}{r}\text { Marks high } \\
\text { school }\end{array}$ & $\begin{array}{r}\text { Education } \\
\text { years }\end{array}$ & High school & $\begin{array}{r}\text { Attacking } \\
\text { others }\end{array}$ & $\begin{array}{l}\text { Arrested } \\
\text { since } 18\end{array}$ & Jail \\
\hline \multirow[t]{2}{*}{ OLS } & -0.474 & -1.335 & -0.267 & 0.384 & 0.257 & 0.157 \\
\hline & $(0.071)^{\star \star \star}$ & $(0.201)^{\star \star \star}$ & $(0.050)^{\star \star \star}$ & $(0.055)^{\star \star \star}$ & $(0.052)^{\star \star \star}$ & $(0.042)^{\star \star \star}$ \\
\hline N & 5270 & 5288 & 5288 & 2180 & 2178 & 2176 \\
\hline \multirow[t]{2}{*}{ FE All } & -0.201 & -0.617 & -0.148 & 0.285 & 0.163 & 0.131 \\
\hline & $(0.074)^{\star \star \star}$ & $(0.260)^{\star \star}$ & $(0.048)^{\star \star \star}$ & $(0.065)^{\star \star \star}$ & $(0.043)^{\star \star \star}$ & $(0.021)^{\star \star \star}$ \\
\hline $\mathrm{N}$ & 5270 & 5288 & 5288 & 2180 & 2178 & 2176 \\
\hline \multirow[t]{2}{*}{ FE Identical } & -0.060 & 0.134 & 0.003 & 0.237 & -0.002 & 0.126 \\
\hline & $(0.136)$ & (0.510) & $(0.097)$ & $(0.127)^{\star}$ & $(0.080)$ & $(0.037)^{\star \star \star}$ \\
\hline $\mathrm{N}$ & 2238 & 2236 & 2236 & 888 & 888 & 886 \\
\hline
\end{tabular}




\begin{tabular}{|c|c|c|c|c|c|c|}
\hline \multicolumn{7}{|c|}{ The effect of four subscales of conduct disorder on positive human capital } \\
\hline $\begin{array}{l}\text { Subscales of conduct } \\
\text { disorder }\end{array}$ & $\begin{array}{r}\text { Marks high } \\
\text { school }\end{array}$ & $\begin{array}{r}\text { Education } \\
\text { years }\end{array}$ & High school & $\begin{array}{r}\text { Attacking } \\
\text { others }\end{array}$ & $\begin{array}{l}\text { Arrested } \\
\text { since } 18\end{array}$ & Jail \\
\hline OLS & 0.014 & 0.052 & -0.019 & 0.116 & 0.016 & 0.015 \\
\hline \multirow[t]{2}{*}{ Aggression } & $(0.017)$ & $(0.061)$ & $(0.012)^{\star}$ & $(0.015)^{\star \star \star}$ & $(0.012)$ & $(0.008)^{\star}$ \\
\hline & 0.046 & 0.052 & 0.019 & 0.040 & 0.025 & 0.012 \\
\hline \multirow[t]{2}{*}{ Destruction } & $(0.018)^{\star \star}$ & $(0.070)$ & $(0.013)$ & $(0.016)^{\star \star}$ & $(0.013)^{\star \star}$ & $(0.007)^{\star}$ \\
\hline & -0.016 & 0.007 & -0.005 & 0.031 & 0.030 & 0.012 \\
\hline \multirow[t]{2}{*}{ Deceit/theft } & $(0.010)$ & $(0.039)$ & $(0.007)$ & $(0.009)^{\star \star \star}$ & $(0.006)^{\star \star \star}$ & $(0.004)^{\star \star \star}$ \\
\hline & -0.119 & -0.409 & -0.056 & 0.020 & 0.027 & 0.015 \\
\hline Violation of rules & $(0.008)^{\star \star \star}$ & $(0.029)^{\star \star \star}$ & $(0.006)^{\star \star \star}$ & $(0.007)^{\star \star \star}$ & $(0.005)^{\star \star \star}$ & $(0.003)^{\star \star \star}$ \\
\hline $\mathrm{N}$ & 5270 & 5288 & 5288 & 2180 & 2178 & 2176 \\
\hline Fixed effect All & 0.028 & 0.035 & -0.009 & 0.100 & 0.007 & 0.004 \\
\hline \multirow[t]{2}{*}{ Aggression } & $(0.019)$ & (0.068) & $(0.013)$ & $(0.018)^{\star \star \star}$ & $(0.012)$ & $(0.006)$ \\
\hline & 0.019 & 0.005 & 0.011 & 0.062 & 0.016 & -0.006 \\
\hline \multirow[t]{2}{*}{ Destruction } & $(0.023)$ & $(0.083)$ & $(0.015)$ & $(0.022)^{\star \star \star}$ & $(0.015)$ & $(0.007)$ \\
\hline & -0.035 & -0.072 & -0.005 & 0.032 & 0.020 & 0.009 \\
\hline \multirow[t]{2}{*}{ Deceit/theft } & $(0.013)^{\star \star \star}$ & $(0.046)$ & $(0.008)$ & $(0.012)^{\star \star \star}$ & $(0.008)^{\star \star}$ & $(0.004)^{\star \star}$ \\
\hline & -0.081 & -0.159 & -0.029 & 0.004 & 0.024 & 0.019 \\
\hline Violation of rules & $(0.011)^{\star \star \star}$ & $(0.039)^{\star \star \star}$ & $(0.007)^{\star \star \star}$ & $(0.011)$ & $(0.008)^{\star \star \star}$ & $(0.004)^{\star \star \star}$ \\
\hline $\mathrm{N}$ & 5270 & 5288 & 5288 & 2180 & 2178 & 2176 \\
\hline Fixed effect Identical & 0.001 & -0.020 & 0.003 & 0.080 & -0.000 & -0.005 \\
\hline \multirow[t]{2}{*}{ Aggression } & $(0.028)$ & $(0.106)$ & $(0.020)$ & $(0.029)^{\star \star \star}$ & $(0.018)$ & $(0.008)$ \\
\hline & -0.046 & -0.070 & -0.002 & 0.116 & 0.030 & -0.004 \\
\hline \multirow[t]{2}{*}{ Destruction } & $(0.033)$ & $(0.125)$ & $(0.024)$ & $(0.037)^{\star \star \star}$ & $(0.023)$ & $(0.011)$ \\
\hline & 0.038 & -0.037 & -0.024 & 0.013 & 0.010 & 0.007 \\
\hline \multirow[t]{2}{*}{ Deceit/theft } & $(0.019)^{*}$ & $(0.073)$ & $(0.014)^{\star}$ & $(0.021)$ & $(0.013)$ & $(0.006)$ \\
\hline & -0.061 & -0.034 & -0.006 & -0.009 & 0.012 & 0.017 \\
\hline Violation of rules & $(0.016)^{\star \star \star}$ & $(0.062)$ & $(0.012)$ & $(0.019)$ & $(0.012)$ & $(0.006)^{\star \star \star}$ \\
\hline $\mathrm{N}$ & 2238 & 2236 & 2236 & 888 & 888 & 886 \\
\hline
\end{tabular}

\begin{tabular}{|c|c|c|c|}
\hline \multirow[t]{3}{*}{ Table A.6 } & duct disord & disorder $\mathrm{s}$ & \\
\hline & \multirow[t]{2}{*}{ OLS } & \multicolumn{2}{|c|}{ Fixed Effect } \\
\hline & & All & Identical \\
\hline \multirow[t]{2}{*}{ Years of CD } & 1.883 & 1.397 & 1.035 \\
\hline & $(0.080)^{\star \star \star}$ & $(0.050)^{\star \star \star}$ & $(0.069)^{\star \star \star}$ \\
\hline \multirow[t]{2}{*}{ Years of CD squared } & -0.134 & -0.102 & -0.073 \\
\hline & $(0.012)^{\star \star \star}$ & $(0.007)^{\star \star \star}$ & $(0.010)^{\star \star \star}$ \\
\hline $\mathrm{N}$ & 5198 & 5198 & 2208 \\
\hline
\end{tabular}

